\title{
Recent Progress in the Rolling Mills-Part $\mathbf{I}^{*}$
}

\section{By Akio SUZUKI**}

\section{Introduction}

In the great expansion of Japanese iron and steel industry to reach the world's third place in the crude steel production, our modernized rolling mills have made a significant contribution. The progress achieved by our universal slabbing mills, hot strip mills, cold strip mills, universal flange mills, and others was on the par with that won by other iron and steel making equipment like large blast furnaces, large oxygen converters and continuous casters. It was not only in the quantity that the progress was apparent but in such quality-intensive fields as the shape, materials, and precision of size that a great accomplishment was made.

It is true that the advent of computer control has aided greatly to labor saving and to operation stabilization as well as to the improvement of product quality just mentioned. But it is also true that behind the remarkable progress attained in the rolling productivity, there has been a close cooperation among the theoreticians, mill fabricators, electric machinery suppliers, and the steel producers in what I would call an organic combination of softwares and hardwares.

In this Nishiyama Memorial Seminar, I shall review the history of rolling equipment in general, then the peripheral technologies that have made those advancements possible, and finally I shall briefly survey the future prospects of rolling.

\section{Progress of Rolling Equipment ${ }^{1-10}$}

\section{Improvements in the Productivity}

It was to meet the enormously increased demand in supply and in variety of steels that enlargement of rolling work stocks like ingots, slabs, billets, hot coils was made, and increase of rolling speed as well as concatenation of rolling mills became necessary also. In keeping with those trends, improvement and development of rolling plants as a whole for better automation and sophistication were intensified to bring about markedly improved operation rate and labor saving. This resulted in simultaneous advancement both in the operation techniques and in the productivity. This is illustrated in Fig. 1.

\section{Increase of Rolling Speed}

The increase of rolling speed for the reversing mills like bloomers and plate mills were achieved by the use of the thyrister-leonard controlling method, which made the quick returning readily possible, on one hand, and by the employment of large diameter rolls, on the other.

In the hot strip mills, it was largely due to increased slab weight that ensured greater rolling productivity and keeping of desired end temperature. To stabilize the product quality, on the other hand, fully continuous, rather than semi continuous, roughers bacame popular, though in recent years quasi-continuous three-quarter rougher train is being reconsidered for versatility.

For the finisher train, the number of tandem stands has been enlarged from 6 stands to 7 . Further, with stiffening of rolls, roll bearings, and mills themselves on one hand, and with advances in AGG

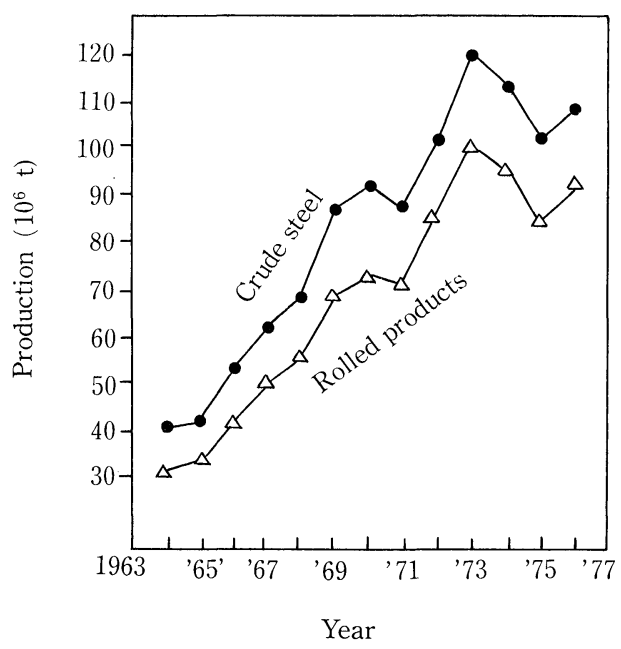

Fig. 1. Progress of Japan's steel production (Statistics due to Ministry of International Trade and Industry).

* Presented to the 57-58th Nishiyama Memorial Seminar, March 1980, at Nogyo Kaikan in Okayama and at Nokyo Hall in Tokyo. Manuscript received September 7, 1983. (C) 1984 ISIJ

Part II will be published in Transactions ISIJ, 24 (1984), No. 4 (April). The contents are as follows:

Chapter IV. Advances of Peripheral Technologies

1. Computer Control

4. Vibration Analysis of Mill Drive

Chapter V. Future Prospects of Rolling Equipment

1. Low Temperature Extraction

3. Shape Control and Plate Crown Control
2. Hydraulic Technologies

5. Fabrication Technology

2. Hot Direct Rolling and Hot Charge Rolling

4. New Rolling Methods

** Kakogawa Works, Kobe Steel, Ltd., Kanazawa-cho, Kakogawa 675-01. 
(automatic gage control) and shape control on the other, the speed of finisher final stand began increasing since about 1950, then hot strip mills with a speed of $1300 \mathrm{~m} / \mathrm{min}$ or more were built in succession since 1967. Today, the fastest rolling speed is over $1600 \mathrm{~m} / \mathrm{min}$, a speed that is very close to the limit of cooling capacity of the strip. This state of affairs is shown in Fig. 2.

In the cold strip mills, the speedup was achieved by the use of the thyrister-leonard control at the main drive motor and by improving the roll bearings, the hydraulic press-down mechanism, and the rolling lubrication technology, the last including refinement of analysis of behaviors of lubricants and emulsions. The results have been a greatest rolling speed of $2500 \mathrm{~m} / \mathrm{min}$.

Up-with-the-speed has also been the standing order for other rolling facilities like pickling, cleaning, recoiling, and skin pass. For example, in the pickling line, the changeover from sulfuric acid to hydrochrolic acid, introduction of mechanical descaler, enlargement of pickling bath, and others have pushed the fastest speed up to $360 \mathrm{~m} / \mathrm{min}$.

In the wire rods mill, speed increase was won by laying out the mills more rationally. The rolling speed, which remained long at about $30 \mathrm{~m} / \mathrm{sec}$ with continuous mills, became 80 to 85 by the advent of fully continuous mills. Today, a speed as fast as $90 \mathrm{~m} / \mathrm{sec}$ is being contemplated. This remarkable acceleration owes its due to the block mill in the finish line, which was first installed in this country back in 1969. An additional merit of increasing of rolling speed has been the increased billet weight, which is now as much as $2000 \mathrm{~kg}$ thanks to the reduced temperature drop during rolling.

The trend has been the same with pipe-making mills also. In the Mannesmann, for example, a boring speed of $60 \mathrm{~m} / \mathrm{min}$ has been attained, this by making the boring angle more acute, the roll dia- meter greater, and revolution speed faster. In the lap welding pipe mill, a combination of 14 stand forge line and a sizer has made a speed of $450 \mathrm{~m} / \mathrm{min}$ quite possible, while in the electric welding pipe mill, replacement of low frequency resistance welder by high frequency resistance welder, then further by high frequency induction welder has ensured a $160 \mathrm{~m} / \mathrm{min}$ for $50.8 \mathrm{~mm}$ (2 in.) mill or $80 \mathrm{~m} / \mathrm{min}$ for $101.6 \mathrm{~mm}$ (5 in.) mill.

\section{Enlargement of Unit Work Stock}

The enlargement and sophistication of rolling mills was not merely to improve the productivity, but also to meet the mounting demands for greater variety in the width, length, and thickness of the rolled products. This necessitated enlarging both the size and the weight of unit work, so much so that today's universal mills can all handle ingots weighing up to $40 \mathrm{t}$-there even is a mill on the design board that takes on $70 \mathrm{t}$ ingots.

The mills themselves became larger naturally, and today the horizontal rolls that used to be 900 to $1000 \mathrm{~mm}$ in diameter are now 1350 to $1400 \mathrm{~mm}$, while the main drive motors of $14000 \mathrm{~kW}$ class are not uncommon where 4000 to $6000 \mathrm{~kW}$ motors were once good enough.

Enlargement in width and weight has been most conspicuous for the heavy plates intended for ships, land structures, and line pipes. The width, which was up to $3048 \mathrm{~mm}$ (120 in.) when the 4-high mills made their appearance, is now $5500 \mathrm{~mm}$ (220 in.). With this widening, reduction and rolling load became much greater. This means a stiffer mill, and today there are mills with main drive motors of $8000 \mathrm{~kW}$ twin, backup rolls of a diameter $2400 \mathrm{~mm}$, and roll stand housings of a column cross section $11000 \mathrm{~cm}^{2}$.

The enlargement of hot strip mills is most apparent in the change in weight of coil and in pound per inch width weight (PIW): in 1960, they used to be $30 \mathrm{t}$
Fig. 2.

Progress of rolling speed of hot strip mill.

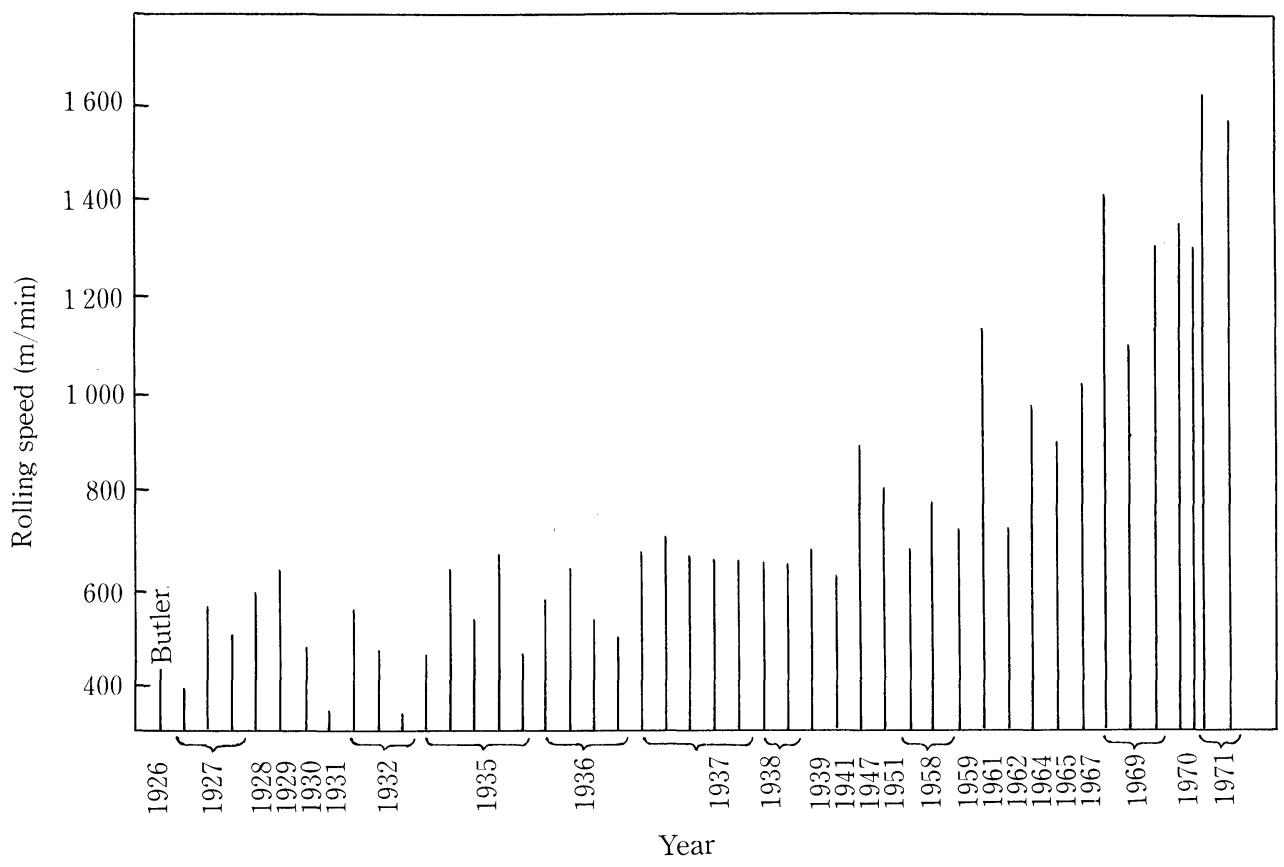


and 10 to $18 \mathrm{~kg} / \mathrm{mm}$, respectively, and today they are as much as $45 \mathrm{t}$ and 20 to $29 \mathrm{~kg} / \mathrm{mm}$.

In the rougher, too, the capacity of the drive motor per stand is increasing rapidly. Moreover, the scale breaker that removes the primary scale is now mostly of the vertical roll type (VSB) rather than the horizontal roll type, and to receive the continuously cast stocks more and more, the VSB, and the rougher edger for that matter, is now popularly of the powerful overhead drive type.

The progress in other rolling equipment is such that, in the crop shear, for example, the thickness is now 40 to $45 \mathrm{~mm}$ rather than conventional $25 \mathrm{~mm}$, and machines that are capable of shearing up to $80 \mathrm{~mm}$ are being planned. In the down-coiler, the maximum thickness has been increased from $12 \mathrm{~mm}$ to over $16 \mathrm{~mm}$, and reels that are able to coil up plain mild steels of up to $25 \mathrm{~mm}$ thickness have been developed to serve in the production of high strength line pipe steels. For the grooming* line, on the other hand, feeders and levelers have been enlarged to perform the straightening and cutting of thick, more than $12 \mathrm{~mm}$, coiled steels. Changes that took place in the hot strip mill are summarized in Table 1.

In the cold strip mills, the capacity of the main drive motor has been increased year by year in correspondence with the progressively enlarged and widened hot strip coil. One mill that was built in 1968 with $2180 \mathrm{~mm}$ width and $40000 \mathrm{~kW}$ total capacity main motor is the greatest both in the mill width and in the motor capacity.

Finally, the demand for pipes for oil wells and oil lines that became especially acute after the Oil Crisis has accelerated the enlargement of pipe-making apparatuses. For example, in the UO press type large diameter welded pipe making, a mill that produces pipes of outer diameter up to $1422.4 \mathrm{~mm}$ (56 in.) was installed in 1970 , then another that produces ones up to $1623.6 \mathrm{~mm}$ (64 in.) outer diameter started operation in 1974. The one common and outstanding feature of those mills is the very large capacity press of $50000 \mathrm{t}$, which is most powerful in the world. In the spiral mills, one that manufactures pipes of $2540 \mathrm{~mm}$ (100 in.) outer diameter with $25.4 \mathrm{~mm}$ wall thickness and $40 \mathrm{~m}$ long is working. Even while the electrically welded pipe mills today can handle works of up to $660.4 \mathrm{~mm}$ ( $26 \mathrm{in}$.) outer diameter, pipes of up to $406.4 \mathrm{~mm}$ (16 in.) outer diameter are being produced by the plug mills.

\section{Concatenation}

Concatenation of mills and continuous rolling have always been among the major objectives of research and development. The 4-high, 5-stand $1425 \mathrm{~mm}$ cold strip fully continuous tandem mill that was commissioned in 1971 is one representative cumulation of such efforts.

The idea of fully continuous rolling had already been realized in an aluminum rolling mill as far back as in 1960, but practicing different rolling schedules all continuously by welding together coils of different thickness and width end to end does merit a special citation. The continuous annealing of cold rolled strips, on the other hand, has been widely implemented in the tinned and galvanized steel lines, but for cold rolled sheets that demand good press formability commercialization has been difficult because of insufficient grain growth and softening. Recently, however, the fast advent of quench-overaging treatment has made continuous annealing a commercial proposition to replace the conventional batch an-

Table 1. Formations of rougher train in recently commissioned hot strip mills.

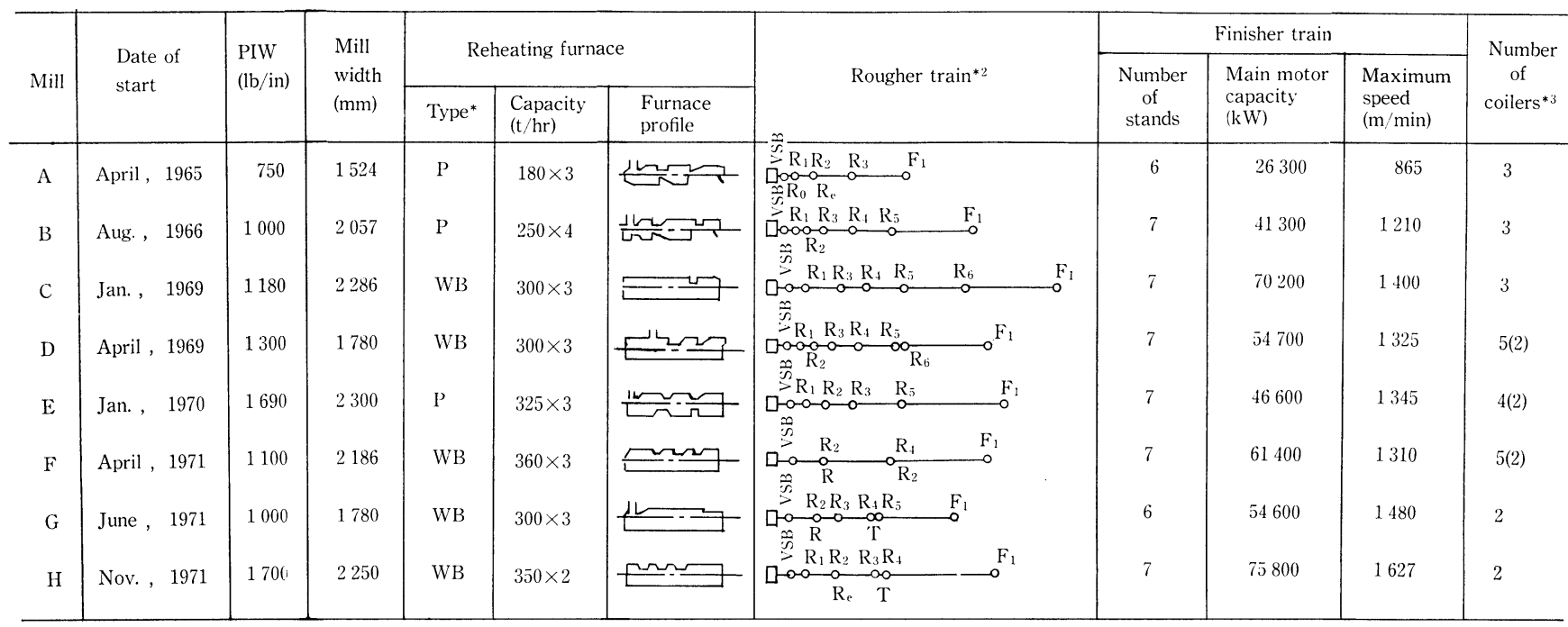

*1 $\mathrm{P}$ : the pusher type, and WB: the walking beam type

*2 $\mathrm{R}_{\mathrm{c}}$ : the reversing type, $\mathrm{R}$ : the returnable type, and $\mathrm{T}:$ the tandem

*3 The parenthesized figures are for the proximity coiler.

* The word "grooming" is proposed for conventional "finishing", because in the modern practice much more QC (quality control) activities are involved here than in ordinary finishing and inspection. 
nealing in a bell jar type furnace. Those continuous annealers that integrate in themselves such auxiliary processes as electrolysis cleaning, skin pass temper rolling, and inspection and grooming have been commissioned successively in 1971 and 1972.

In the area of high flow strength materials like stainless steels, the traditional Sendzimir reversible mill is being replaced by tandem mills as problems of top threading, welding of high $\mathrm{Cr}$ steels and lubrication were solved. The $1300 \mathrm{~mm}, 20$-high, 4-stand tandem mill that became operational in 1969 is one example.

As for the shape mill, by its very nature of having to perform three-dimensional deformation the analysis of rolling characteristics was lagging behind the fast advancing plate rolling theories, but a recently developed technology of controlling the inter-stand tension at a value near zero has made true continuous mill to appear. The first such mill was a large tandem line that concatenated one rougher and two finishers built in 1971. Then, three intermediates and four finishers (all universal type) were made continuous by means of the motor current memorizing control method. This tandem mill is known for its high productivity, some three times that of old practice.

Other technologies that are famous for their great effects on energy saving are the hot direct rolling (HDR), in which bloomer is connected to hot strip mill by sending the red hot slabs directly, and the hot charge rolling (HCR), where the hot slabs are charged into the reheating furnace. In the present state of practice, the HDR remains 20 to $45 \%$ and the HCR 10 to $20 \%$ in application to the hot strip mill, but with the world energy situation showing no prospects of improving, fast spreading is forecast.

\section{Technical Rationalization}

Besides those sophistication of rolling mills for enlargement, acceleration, and concatenation, new technologies to cover the impending labor shortage have become important.

Those devices that have been seen in the bloomer are the driver of the vertical rolls, the quick changer for both the vertical and the horizontal rolls, and the cassetted knives for the shear, and also the manipulator, the ingot buggy, and the run table. In the grooming line, slab coolers of either the submerging or the spray type that were developed to shorten and simplify the process, while spot scarfing machines, and grinders that can be readily automated to replace the conventional hand scarfer are gaining rapid recognition.

In the plate mill shop, improvements are seen everywhere from reheating furnace to grooming line, but most noteworthy is the rationalized layout and the fast process computer.

In the hot strip mill, the quick roll changer is the most clearly advanced. Where the roll change used to be done with a porter bar or a $\mathrm{G}$ hook, today every one of the operating mills is equipped with an appropriate number of quick roll changers of either the side shift type or the turntable type so that several stands may be attended to simultaneously (Fig. 3). Other apparatuses of notable labor saving and quality assurance is the direct transfer line that connects the roll changer tables to the roll shop, the chock quick assembler, the roll automatic dressing machine, and the chock grinder.

In the hot down-coiler, there is one that is known as the proximity coiler which is installed particularly close to the finisher so as to shorten the threading time. Other improvements for shortening the threading time are seen in the guides, loopers, hot run tables, pinch rolls, and wrapper rolls; also the automatic marking machine and the automatic bundler have proved effective for labor saving.

In the cold strip mill as in the hot strip mill, shortening of roll changing time has been successfully achieved by introducing quick changers. Also, the fully automatic coil handlers at both the entry and the delivery sides and the automatic threading apparatus have made fast threading possible.

In the wire rods mill, which features multi-product, small lot production, marked improvement is seen in the roll exchanger for universal mill. In the stand changing type, in particular, the newly developed automatic coupler and spindle positioner have been instrumental in shortening the roll changing time.

\section{Improvement in Quality}

It was not only by the progress of mass production technology that we have achieved the world's supremacy, but those various advanced technologies for quality improvement have had a great deal to do with it. In the technologies for betterment of quality, besides those of rolling equipment, rolling theories, electric measuring and controlling devices, and lubrication, the computer technology must not be overlooked. By computer technology, I refer particularly to the stabilization of quality and assimilation of control information by the use of fast process computers.

In the gage control, enlargement of backup roll diameter, strengthening of mill rigidity by enlarging the roll housing columnar cross section, and thyrister-

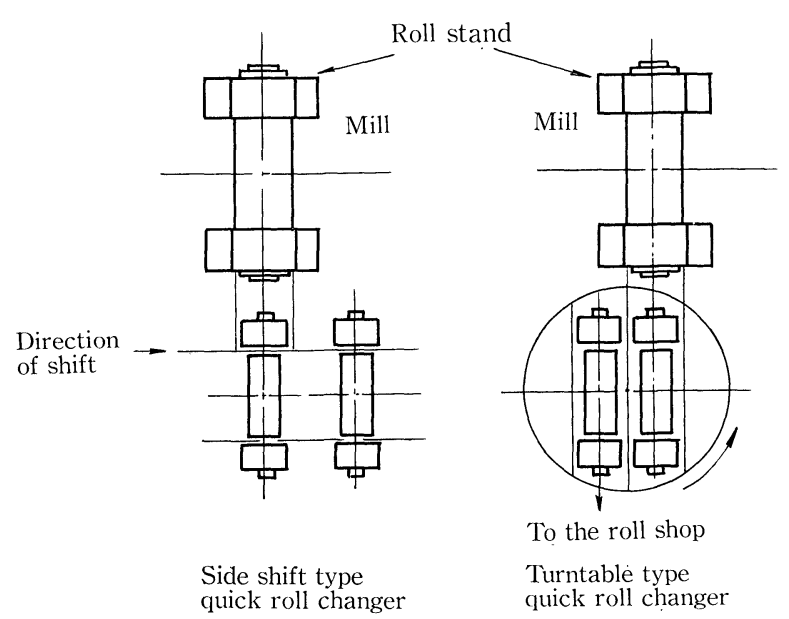

Fig. 3. Examples of quick roll changer. 
leonard control of driver, that is, those means that help reduce the fluctuation of thickness in accordance with changes in the flow stress in the work, have been introduced. In the recent mills, moreover, AGG with various built-in feedback circuits has improved the gage controlling remarkably, particularly when aided by the computed variables setting-up control method. To augment this AGG's merit, hydraulic press-down is being introduced to the hot rolling mills as well as to the cold rolling mills.

In the cold tandem mill, a mill in which the mill rigidity can be controlled as desired in accordance with the rolling characteristics has made its appearance. Also, as a means to compensate for the changes in the characteristics of hydrodynamic bearing during acceleration and deceleration, dynamic control is being practiced. And, for this purpose, roller bearing is being tried on the backup roll bearings.

As for the shape control, after the earlier development of the roll bending method, development of shape detectors for automatic controlling is in the foreground today.

Other topics of more recent years are the 6-high mill of a special structure that claims to be able to give a much improved cross section profile and shape, the differential rolling method in which the upper and the lower work rolls are driven at a different speed making large reduction rolling possible, the walking beam reheating furnace equipped with new skid and extractor, the high pressure water jet descaler, the water spray method of rolling temperature control, the edge heater for slabs, and many others.

I submit that without those large rolling apparatuses, let alone the progress in the metallurgy and temperature controlling, our high quality plate steels of outstanding as-rolled low temperature toughness, to mention just one example, have not been given births to.

\section{Recent Rolling Equipment}

As a result of intensive and extensive research and development and of operational know how accumulated over a long time, numerous rolling apparatuses have made their appearances one after another. They encompass from small equipment to an entire plant, but, for want of time and space, only several that appear to me to be worthy of special citation will be discussed here.

\section{Hydraulic Press-down}

The hydraulic press-down, which was first applied in 1964 to a reversing mill, was steadily improved until it started replacing the conventional electric press-down in the cold strip mill in 1968. The changeover was so successful that today not only all the cold strip mills of this country are of the hydraulic press-down, but invasion into the plate mills and hot strip mills has begun. That is, today we have an age of hydraulic press-down.

This is due largely to the improvements achieved in the electrohydraulic servo valve, the pickup, and the control technique, the results of which have been the quick response, high precision control of roll position, the variable mill stiffness control, the compensatory control for acceleration and deceleration, the compensatory control for roll eccentricity, and the tension control in accordance with press-down, namely those delicate controllings that were not good enough with electric press-down. ${ }^{12-14,17,18)}$

\section{Progress in the Hydraulic Press-down}

In Fig. 4, I have illustrated the evolution of the press-down mechanism. First came the mechanical servo type, in which the reference point was the position of the intermediate cylinder ram, which was detected by amplifying its displacement relative to the press-down cylinder by means of oil enclosed between them and was mechanically fed back to the press-down cylinder. In this method, though the maintenance was easy, the response was not too fast because of the limitation in the servo valve performance and necessarily elongated piping. Nevertheless, this method is being used even today for it is good enough for many applications.

Then, in 1968 to 1972 , the tension, or the compression, bar type became popular. In this method, the roll gap is detected by the load cell built in the bar. Though the sensitivity was greater in the lower frequency range, the rather narrow control range due to limitations imposed by the length and rigidity of the bar and the complexity of the structure were the problem. ${ }^{15}$

Since 1973, analogue detectors have been being replaced by such digital detectors as the magnetic scale type or the inductosyn type that are capable of determining position at a high precision with a resolution of $1 \mu \mathrm{m}$ regardless of the gage length. Today, direct detection of the position of ram or chock is quite feasible with those detectors, and also the structure has been much simplified. ${ }^{17)}$ Recently, the electronic scaling type that combines electrohydraulic servo valve and those digital detectors is making appearance as the most advanced hydraulic pressdown control component.

Those are compared in Fig. 5, ${ }^{19)}$ and are functionally classified in Table $2 .{ }^{11)}$

\section{Application to Various Rolling Mills}

Adoption of the hydraulic press-down has been quicker and wider for the cold strip mills than for any other. Today, both the mechanical servo type and the electric scaling type are being employed, and with electric scaling types fast response such as 40 msec for step response and $15 \mathrm{~Hz}$ for frequency response has been achieved in the roll position control.

In the plate mill, too, hydraulic press-down is being employed by recent mills, because the high load, high speed AGC rolling demands such mechanical stiffness and very fast response that the electric press-down cannot meet. That is to say, in heavy plate rolling, because of the large irregularity in the thickness of incoming plate arising out of the temperature irregurarity at the skid marks, high speed and large reduction rolling is a necessity. For this, the flow rate through the servo valve need be large, meaning large capacity servo valves and a large oil 
reservoir. So much so that a heavy plate mill hydraulic press-down that was commissioned recently is equipped with a $300 \mathrm{~kg} / \mathrm{cm}^{2}, 800 \mathrm{l} / \mathrm{min}$ high pressure servo valve and 1600 to $1650 \mathrm{~mm}$ diameter, 5000 to $6000 \mathrm{t}$ cylinders for AGG.

The situation is much the same in the hot strip mill as in the plate mill, and here again adoption of hydraulic press-down has already begun. ${ }^{16)}$

\section{Power Down-coiler}

The upper limit of a hot strip mill product gage is practically determined by the down-coiler, whose

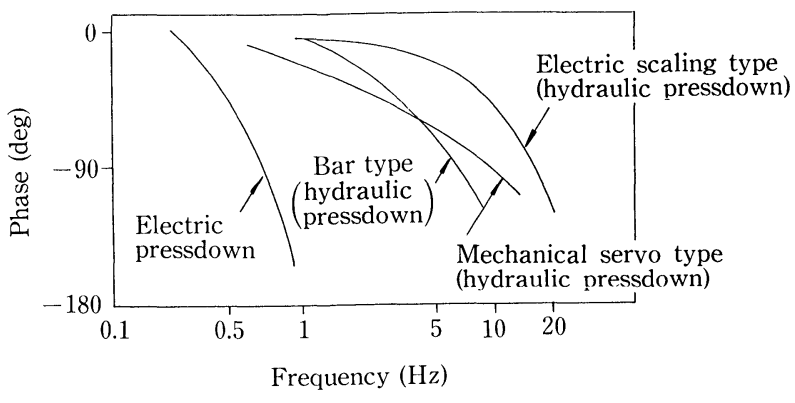

Fig. 5. Frequency responses of various type press-down.

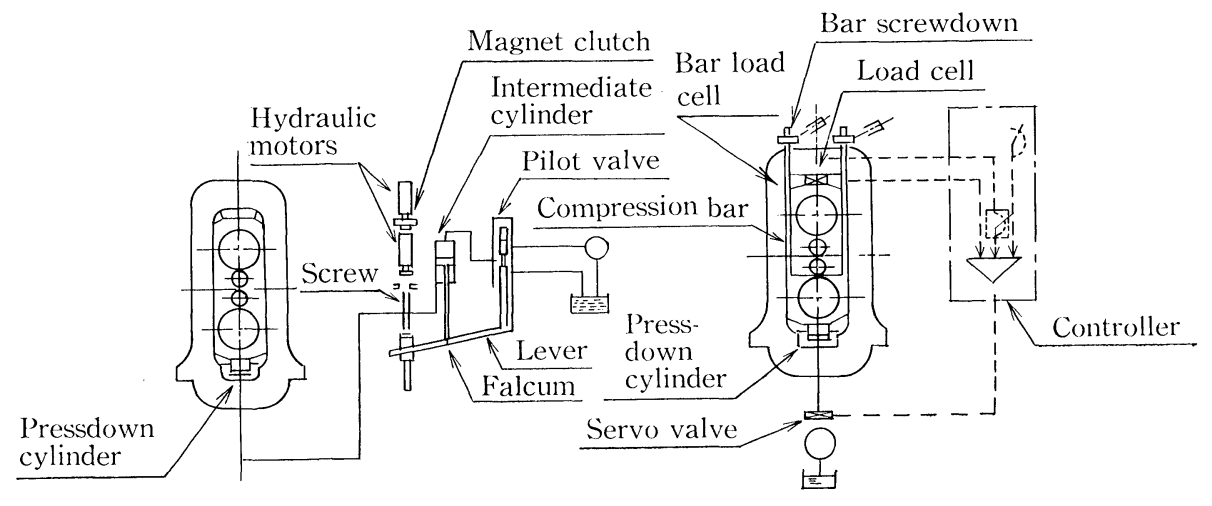

(1) Mechanical servo type

(2) Compression bar type

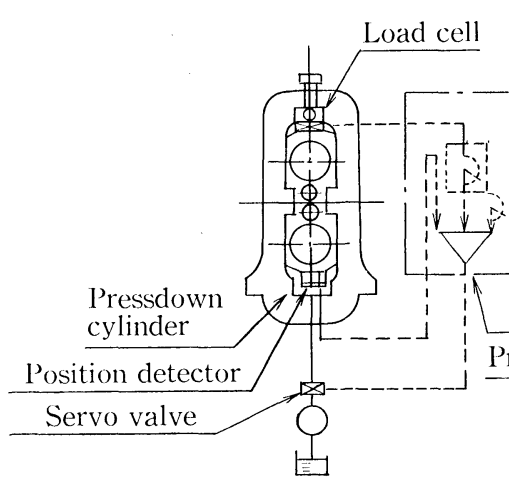

(3) Ram position detecting electric scaling type

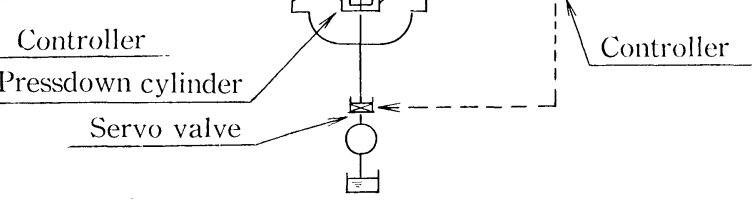

(4) Chock position detecting electric scaling type

Fig. 4. Various types of hydraulic press-down control.

Table 2. Functional classification of hydraulic press-down.

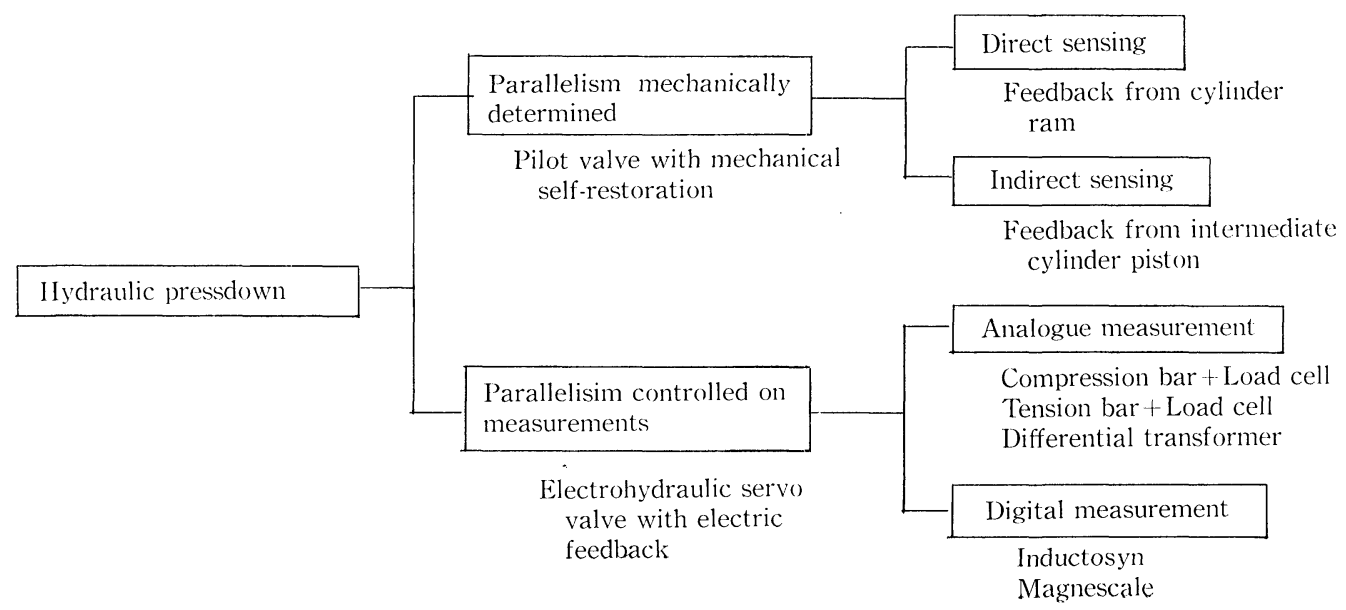


ability is expressed in terms of the mandrel axial torque, which is continually on the increase as shown in Fig. 6. As may be seen here, the progress has been very rapid, and in 1968 a down-coiler of $9.4 \mathrm{t}-\mathrm{m}$ made its debut, making coiling of $19 \mathrm{~mm}$ gage plain carbon steel possible. Since then, increased demand for high strength line pipe steels had accelerated the progress, and the years after 1971 have seen the emergence of machines of mandrel torque of over $13 \mathrm{t}-\mathrm{m}$, namely, the so-called the power down-coilers. With those coilers, making of coils out of mild steels of up to $25.4 \mathrm{~mm}$ is quite feasible and the range of products of hot strip mill has been expanded enormously.

I wish to discuss those power down-coilers in comparison with conventional ones in the following.

\section{Mandrel}

Generally, the down-coiler mandrel is of the 4 segment, hydraulic expansion type, of which the expander is either of the link mechanism or the wedge mechanism. Recently, however, the 3 to 5 wedges type is gaining popularity for its potency against segment deformation and pin wearing. In the power down-coilers, on the other hand, though their mandrels are not much different structurally from the conventional, internal forced-cooling is practiced to prevent the segment from deforming under regenerating heat.

\section{Mandrel Driver}

A large torque is necessary to coil up a thick strip, but then the high torque mandrel is unfit for thin strips because troubles like necking are apt to occur. Therefore, the power down-coilers are equipped with a switchable reduction gear so that low speed, high torque drive for heavy gage works and high speed, low torque drive for light gage stocks may both be practiced. Figure 7 shows some ways of choosing the high or the low torque drive.

\section{Pinch Roll and Wrapper Roll}

As the torque need to bend a strip at a pinch roll is proportional to a square of the thickness, the drive motor must correspondingly be large to handle heavy gage strips. In recent year, the power downcoiler motors have progressively become larger, and the greatest is as big as $1000 \mathrm{~kW}$ (Fig. 8).

The pinch roll press-down force that remained to

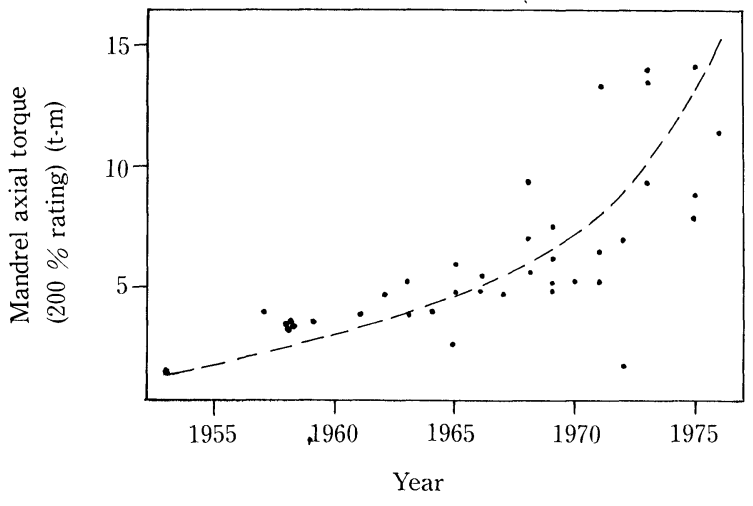

Fig. 6. Progress of down-coiling force. be on the $10 \mathrm{t}$ level, on the other hand, has been strengthened to 60 to $150 \mathrm{t}$ for the power down-coilers. For this, the pinch roll frame is now much stiffened, and there is at least one instance where an additional roll is provided to push the strip down when it is particularly thick, so as to ensure sufficient bending and to prevent it from "floating" at the pinch roll entry side.

A large press-down force is needed for the wrapper roll of a power down-coiler also, because the wrapper is expected to work to help bend the strip. And, as it is subjected to a great impact when receiving the strip and when the second strip comes into overlapping on the first, the diameter of wrapper roll is necessarily large. There even is a down-coiler, therefore, that is equipped with a shock absorber to improve the response at the same time.

\section{Controlling}

The feature of mandrel control at power downcoilers is the controlling of the maximum torque for the reel and that of bending torque. The maximum torque reel control is to maintain the tension constant while utilizing the motor power to a greatest extent to develop the large tensile force needed to reel in a very thick gage strip, whereas the bending torque control is to change the bending force in accordance with the increasing coil diameter so as to maintain the tension constant, all depending upon the properties of the thick strip being reeled in.

\section{High Speed Pickling}

The use of hydrochrolic acid in large pickling line

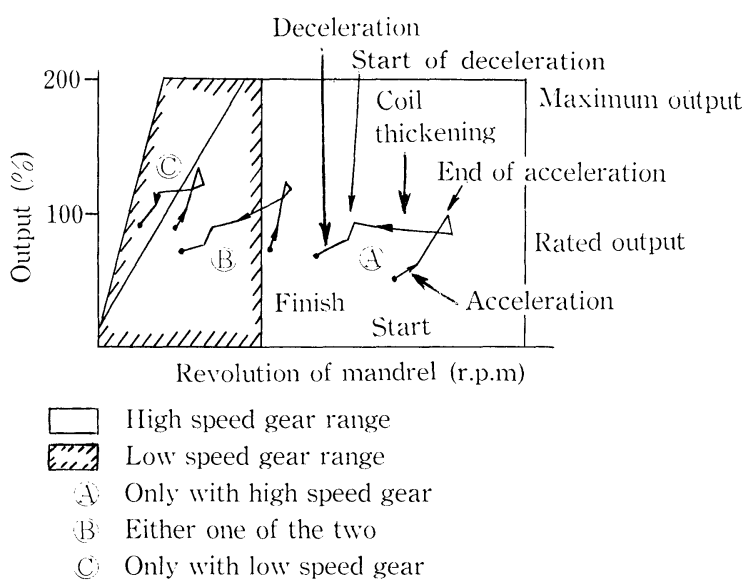

Fig. 7. Notion for selection of gear.

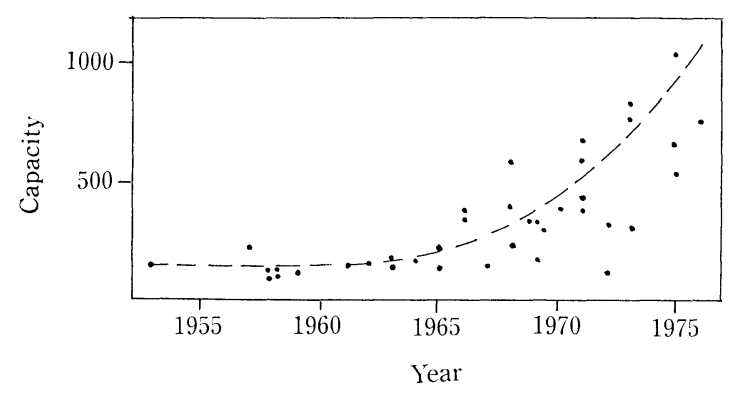

Fig. 8. Progress of pinch roll main-drive motor. 
dates back to M. Clouth Co.'s tower pickling line of 1963 , and in this country it is rapidly spreading since a horizontal pickling line that had a built-in acid recovery unit was installed in 1966. Since then, many improvements have been done in raising of speed, automation, labor saving, and environmental protection, and today, 31 out of operating 42 pickling lines are using hydrochrolic acid, of which one boasts a capacity of over $120 \mathrm{kt}$ a month.

\section{Speed-up, Automation, and Labor Saving}

In Fig. 9, the changes in the pickling line speed are shown by the central part speed. ${ }^{21)}$ The increase of speed after 1965 to the present level of $360 \mathrm{~m} / \mathrm{min}$ is quite remarkable, and this owes to the increased descaling rate on changing from sulfuric acid to hydrochrolic acid, enlargement of the bath, increased amount of immersed steel, and improved component apparatuses.

To meet the much increased coil weight, which today amounts to $45 \mathrm{t}$ at the entry and $60 \mathrm{t}$ at the delivery ends, further, various refinements in automation have been made for optimum control and labor saving. The more noteworthy ones are as follows.

1) Coil Handling Facilities: coil transfer machine, threader, automatic welder, side guide width setter, automatic bundler, and automatic deceleration and stop

2) Controllers: computer control (Table 3), loop controller, acid $\mathrm{pH}$ controller, and automatic weigher

3) Inspection and grooming facilities: crownmeter, widthmeter, lengthmeter, and surface flaw detector

\section{(1) Scale Breaker}

Earlier on, the scale breaker is often omitted in the hydrochrolic acid pickling lines, but this is being reconsidered as the secondary scale breaker is gaining popularity for its effect of restoring the descaling efficiency, which has been on deterioration under the prevailing high temperature reeling-in practice. ${ }^{22)}$ The scale breaking, which is performed by straining the strip surface, is analyzed in Fig. $10,{ }^{23)}$ from which

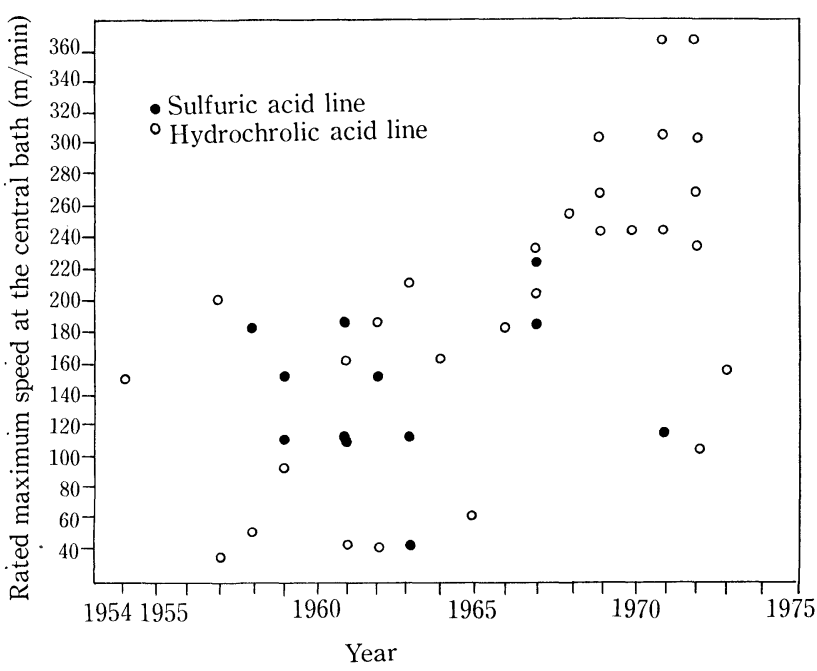

Fig. 9. Progress of pickling line speed (at the central bath). the popularity for the bending/tensile method and the skin pass rolling method may be understood. An example of usage in an actual line, where the bending/tensile method is practiced in front of the pickling bath, is illustrated in Fig. 11. It is said that

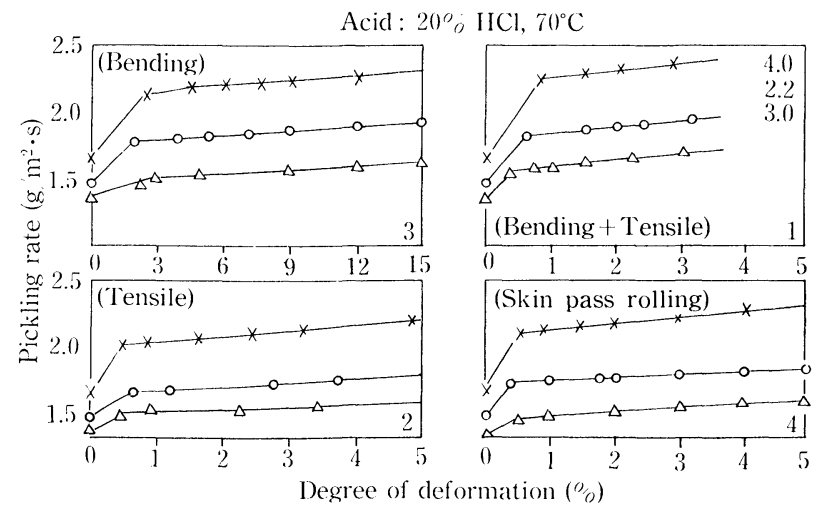

Fig. 10. Comparison of various methods of scalebreaking.

Table 3. Functions of computer control.

\begin{tabular}{|c|c|c|c|}
\hline Objective & $\begin{array}{l}\text { Functions } \\
\text { (Setting of } \\
\text { variables) }\end{array}$ & Control means & $\begin{array}{c}\text { Number } \\
\text { of } \\
\text { variable } \\
\text { set up }\end{array}$ \\
\hline Tracking & $\begin{array}{l}\text { Sequence of } \\
\text { rolling }\end{array}$ & Lengthmeter & 2 \\
\hline Uncoiler & Leveler gap & $\begin{array}{l}\text { Leveler press-down } \\
\text { APC* }\end{array}$ & 3 \\
\hline $\begin{array}{l}\text { Shear } \\
\text { (Entry } \\
\text { end) }\end{array}$ & $\begin{array}{l}\text { Width between } \\
\text { side guides }\end{array}$ & $\begin{array}{l}\text { Shear front and back } \\
\text { side guides APC* }\end{array}$ & 2 \\
\hline Welder & $\begin{array}{l}\text { Welding } \\
\text { conditions }\end{array}$ & Welder controller & 10 \\
\hline \multirow{2}{*}{$\begin{array}{l}\text { Automatic } \\
\text { control } \\
\text { (Exit } \\
\text { end) }\end{array}$} & $\begin{array}{l}\text { Change of } \\
\text { mode }\end{array}$ & $\begin{array}{l}\text { Outlet sequence } \\
\text { controller }\end{array}$ & 3 \\
\hline & $\begin{array}{l}\text { Length of } \\
\text { divided coil }\end{array}$ & $\begin{array}{l}\text { Outlet automatic } \\
\text { deceleration }\end{array}$ & \\
\hline $\begin{array}{l}\text { Unholding } \\
\text { rolls }\end{array}$ & $\begin{array}{l}\text { Width between } \\
\text { side guides }\end{array}$ & $\begin{array}{l}\text { Unholding side } \\
\text { guides APC* }\end{array}$ & 1 \\
\hline \multirow[t]{2}{*}{$\begin{array}{l}\text { Side } \\
\quad \text { trimmer }\end{array}$} & $\begin{array}{l}\text { Width between } \\
\text { side guides }\end{array}$ & $\begin{array}{l}\text { Side trimmer side } \\
\text { guides APC* }\end{array}$ & 1 \\
\hline & $\begin{array}{l}\text { Width between } \\
\text { side trimmers }\end{array}$ & $\begin{array}{l}\text { Side trimmer width } \\
\text { APC* }\end{array}$ & 2 \\
\hline $\begin{array}{l}\text { Deflector } \\
\text { roll }\end{array}$ & $\begin{array}{l}\text { Width between } \\
\text { side guides }\end{array}$ & $\begin{array}{l}\text { Deflector roll side } \\
\text { guides APC* }\end{array}$ & 1 \\
\hline \multirow[t]{2}{*}{ Oiler } & $\begin{array}{l}\text { Selection of } \\
\text { a corrosion } \\
\text { preventive oil }\end{array}$ & Oiler controller & 1 \\
\hline & $\begin{array}{l}\text { Width between } \\
\text { nozzles }\end{array}$ & Oiler controller & 1 \\
\hline $\begin{array}{l}\text { Width- } \\
\text { meter }\end{array}$ & $\begin{array}{r}\text { Width and } \\
\text { tolerance }\end{array}$ & $\begin{array}{l}\text { Measuring instru- } \\
\text { ment }\end{array}$ & 3 \\
\hline $\begin{array}{l}\text { Thickness- } \\
\text { meter }\end{array}$ & $\begin{array}{l}\text { Thickness and } \\
\text { tolerance }\end{array}$ & $\begin{array}{l}\text { Measuring instru- } \\
\text { ment }\end{array}$ & 3 \\
\hline $\begin{array}{l}\text { Ultrasonic } \\
\text { detector }\end{array}$ & $\begin{array}{l}\text { Breadth of } \\
\text { transducer }\end{array}$ & $\begin{array}{l}\text { Transducer APG* } \\
\text { and measuring } \\
\text { instrument }\end{array}$ & 2 \\
\hline
\end{tabular}

* APC : Automatic position control 


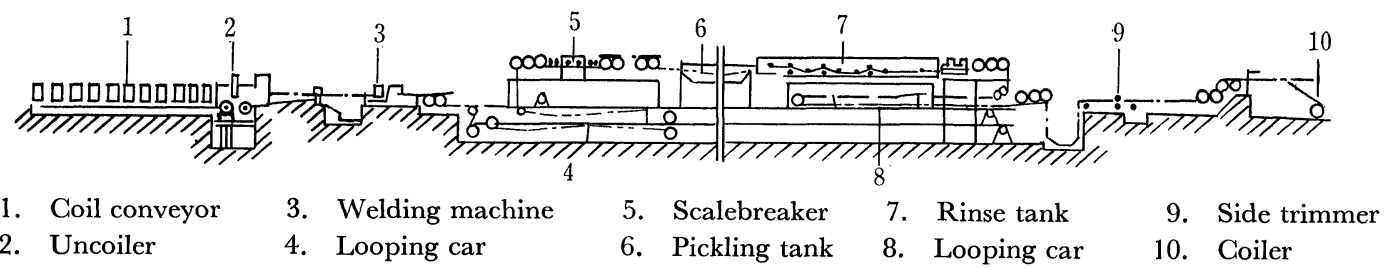

Fig. 11. Actual example of placing the scalebreaker in the line.

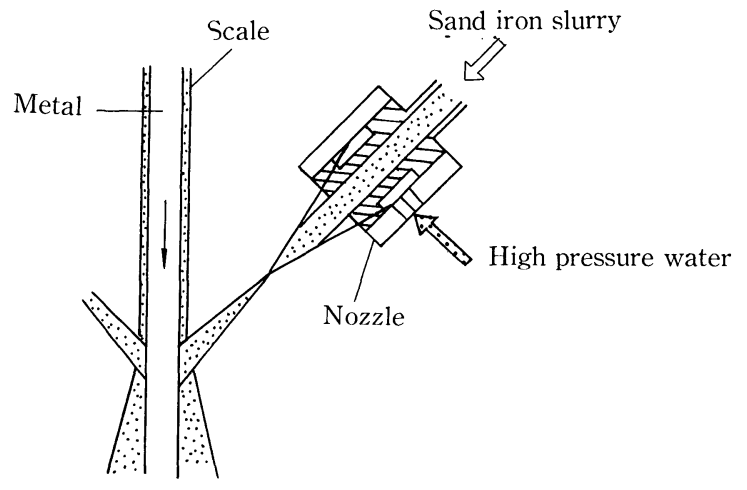

Fig. 12. Principle of mechanical descaling.

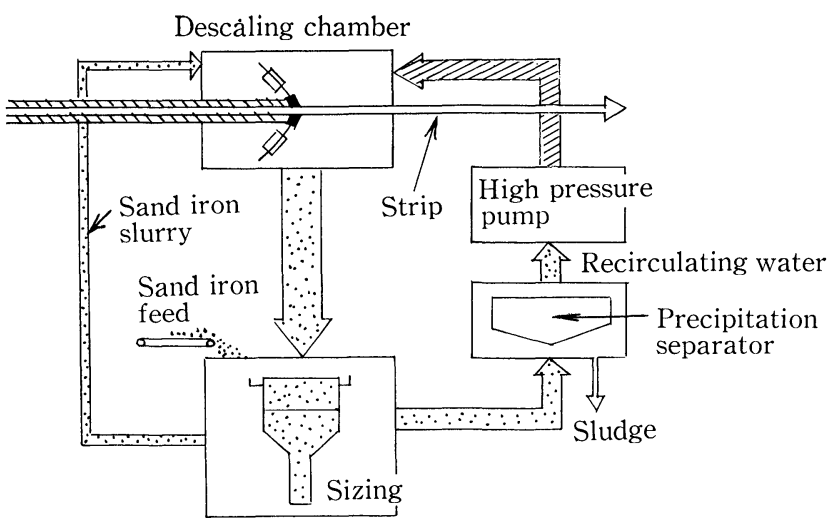

Fig. 13. A mechanical descaling system.

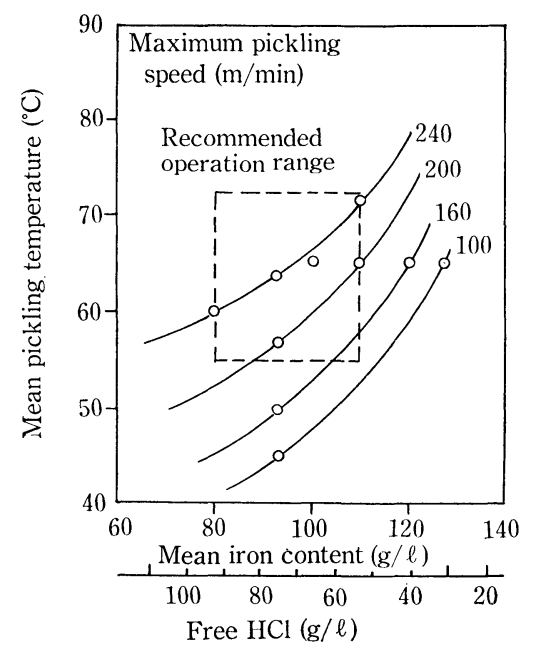

Fig. 14. Effects of concentration and temperature on pickling speed. the effect of scale breaking is equivalent to some $10 \%$ increase in the pickling rate. ${ }^{44}$

On the other hand, the mechanical descaling, that does not use any acid at all, is approaching commercialization. One such apparatus is illustrated in Fig. 12 for its operating principle and in Fig. 13 for the system. ${ }^{25}$ )

(2) Temperature and Concentration Control

The rate of pickling depends very much on the acid concentration and temperature as shown in Fig. 14. Of the two, the acid concentration is controlled by the quantity of the recirculated fluid, and here a method in which the recirculatory flow rate is controlled as a function of the surface area of the strip to be pickled and is corrected by automatically determining the iron content of the waste acid overflowing the bath. ${ }^{26}$ ) This method is known to ensure an optimum operation and an increased pickling rate.

The heating of the acid, which is being done commonly with steam, can be either direct or indirect. That is, the steam may be injected straight into the bath or be used as the working medium of heat exchanger. In the latter, the out-of-the-bath method, in which the acid is led to the heat exchanger located outside of the bath, is becoming popular.

Other innovations of note for energy saving and prevention of acid hume pollution are the floating lid and the intermediate cover, which is placed inside the ordinary bath cover, and both are said to be worth some $7 \mathrm{~kg} / \mathrm{t}$ saving in the steam rate. ${ }^{22)}$

3. Curtailment of Downtime at Entry and Delivery Ends

\section{(1) Automatic Welder}

To improve the commonly used flush butt welder that needs the work to be cut, welded, and trimmed at different positions along the line, a new type automatic welder is in the offing. ${ }^{27,28)}$ This machine has a built-in shear, so that those three operations are conducted at the same position on the two strips that are clamped end on end, and some 30 precious seconds are saved.

(2) Loop Accumulators at Entry and Delivery Ends

For the strip accumulation at entry and delivery ends, the loop car type is common, and usually 2 to 3 stages are provided beneath the pickling bath. Further, as may be seen in Fig. 15, the amount of accumulation has been on the increase as the line speed is.

\section{Spray Cascade Rinsing}

Rinsing is performed at the delivery end of the pickling bath, where the amount of spray water had to be increased as the line speed was increased, and 
today in some lines it is already over $100 \mathrm{~m}^{3} / \mathrm{hr}$. To save on the water, the cascade rinse method that permits of the use of recirculated water is commonly adopted. In the system shown in Fig. 16, the quantity of fresh water that is to make up at the last tank is no more than about $10 \mathrm{~m}^{3} / \mathrm{hr}$, while the waste water that overflows the first tank is of an iron content of about $80 \mathrm{~g} / l$ with an acid concentration of about $2 \%$. This makes the acid recovery easy. ${ }^{30,31)}$

\section{Fully Continuous Cold Rolling Mill}

The fully continuous rolling, which was first advocated by Lenze in the $1960 \mathrm{~s},{ }^{32}$ ) was realized in the aluminum rolling and with Sendzimir mill in the special steel rolling. However, the world's first truly fully continuous mill, that is, in the meaning of that the mill is capable of taking different width, different gage coils of mild steel without interruption, is the $1425 \mathrm{~mm}, 5$ stage tandem mill that was commissioned in 1971. This mill is a culmination of long experi-

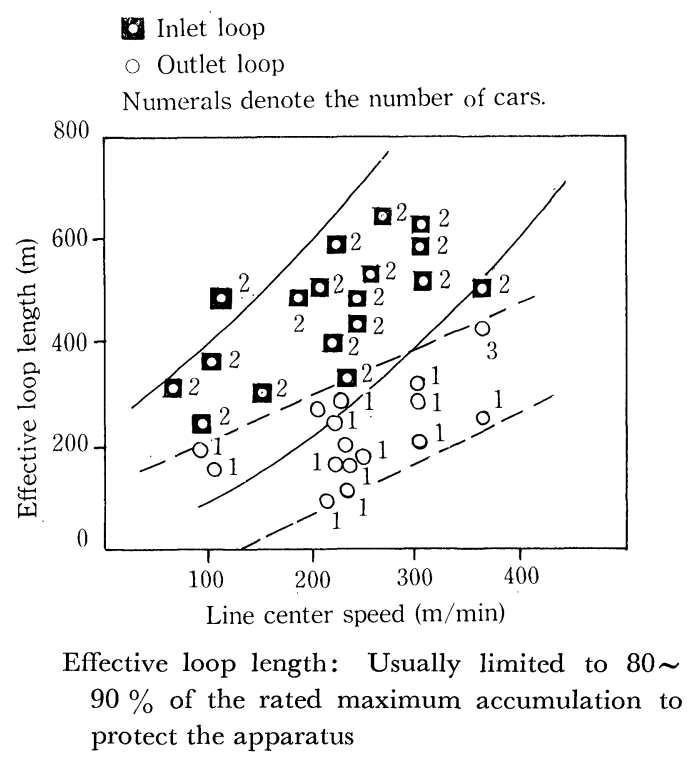

Fig. 15. Relation between line speed and loop capacity. ences refined in the conventional tandem mills and various newly developed technologies. As the continuous mill promises improved productivity, yield, and quality, as well as labor saving, at a certain expense in the capital investment, it is steadily gaining popularity since its appearance. ${ }^{33-35)}$

\section{Formation of the System}

The equipment system of computer controlled fully continuous cold rolling mill is exemplified in Fig. 17.

(1) Equipment for the Rolling Mill

Though the rolling mill itself is not much different from the conventional tandem mill, special features are seen in the entry and the delivery equipment.

(i) Entry End Equipment

To carry on the rolling operation even while the strip is stopped for welding of the succeeding coil, loop car type accumulator is provided. The designing of the accumulation should be done on the weight of coil, welding time, rolling speed, and production rate desired to be the most economical. Examples are shown in Fig. 18.

At the entry end, further, backward tension is imposed on the No. 1 stand by means of a bridle to prevent the snaking, and application of oil should be refrained to forestall slipping.

As the welded joint is an important demarcation to define the coil-to-coil junction and the point of change of gage control for the flying strip, it need

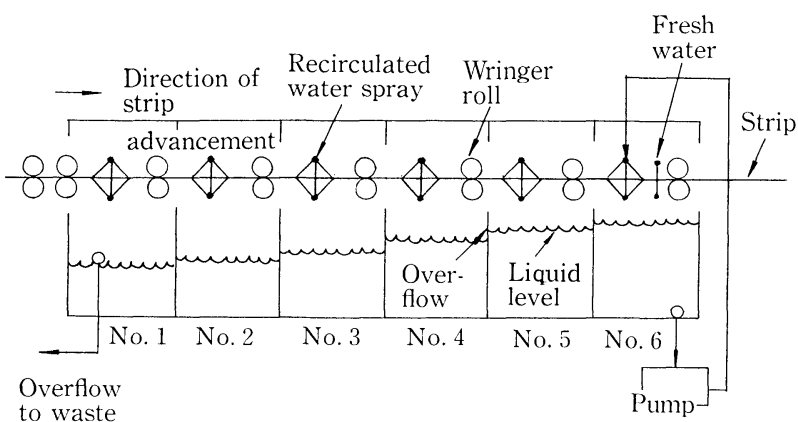

Fig. 16. Structure of cascade rinse line.

Spraying of recirculated water is done at every bath.

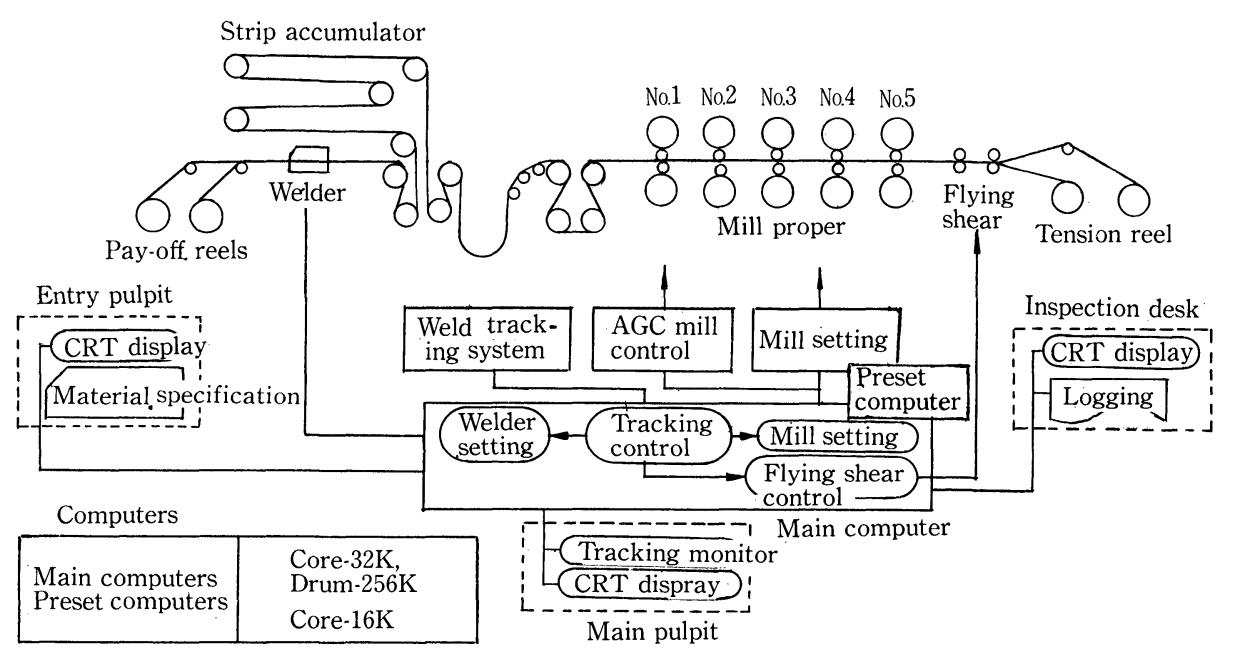

Fig. 17. Fully continuous cold strip mill line and computer control system. 

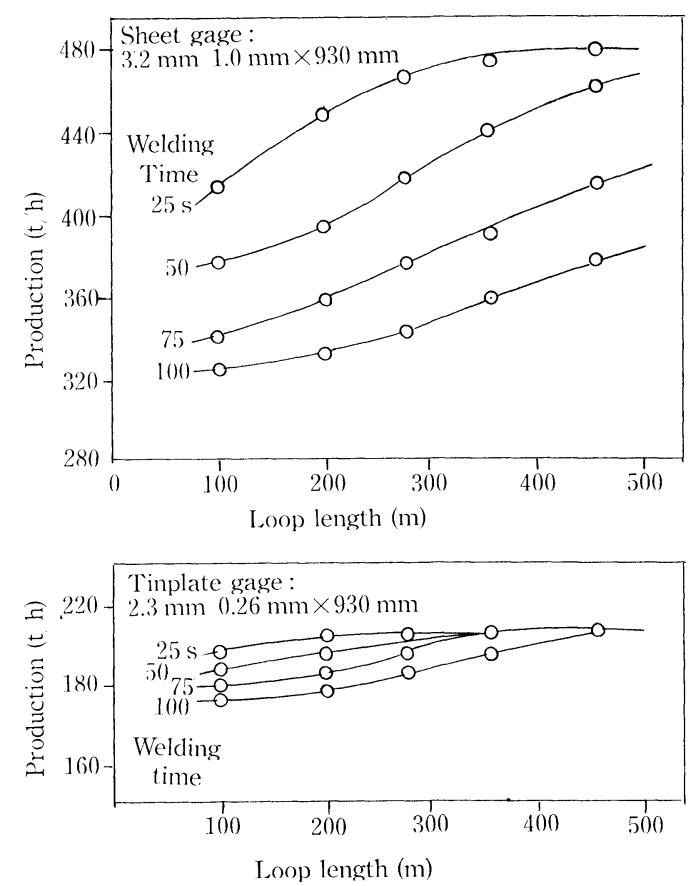

Fig. 18. Effects of welding time and loop accumulation on productivity.

be detected precisely at the entry end of the line. For this, the magnetic permeability detection method and the magnetic marking method are available.

(ii) Mill Proper

As such troublesome works as threading or tending to the runaway strip are no longer necessary, the threading guides that crowd the stand at the entry side are all but eliminated, and the merit of simplification is considerable. Further, the mill housing and the roll chock are specially designed so as to make the work roll change easy and quick.

(iii) Delivery End Equipment

Here, the strip is sheared while flying and fed alternatingly to the proper one of the pair of the downcoilers, by means of the selector gate, keeping the rolling speed at over $250 \mathrm{~m} / \mathrm{min}$. For this, devices to prevent the lancing or buckling are provided.

(2) Computer Control

The computer controlling is indispensable with a fully continuous cold rolling mill. The functions expected of the process computer are summarized in Table 4.

\section{(i) Coil Tracking}

Continually following the flying strip, the computer tracks out the progress of rolling by detecting the pickled welded part and the mill welded part, determines by computation points of the gage change and shearing point, and issues out an appropriate action command.

(ii) Flying Alteration of Gage and Width

This is a technique that allows the pass schedule to alter and the strip gage to change suddenly, and is the most important among the functions of computer. For this, the dynamic chronological alteration actions must be excuted precisely in accordance with the computations done in advance.
Table 4. Functions of control computer.
Goil tracking

Leveler gap setting

Side guide position setting

Welder setting

Strip accumulator control

Flying alteration of gage and width

Mill speed control
Tension control

Droop setting

Roll bender setting

Automatic lap check

Operation record and data logging

CRT display
Flying shear operation

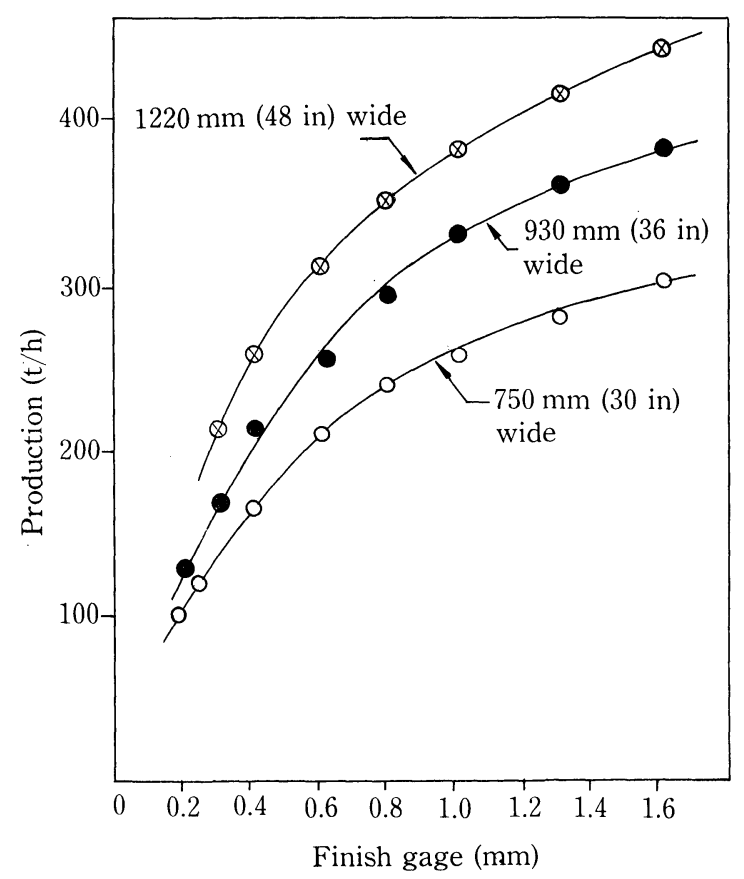

Fig. 19. Actual productivities experienced in a fully continuous cold strip mill.

\section{Features of Fully Continuous Cold Rolling Mill}

As mentioned a little earlier, the greatest merit of fully continuous mill lies in the freedom from troubles of threading and runaway strip. From this, and aided by the computed control, many features are derived.

For example, thanks to this freedom, the downtime is very much cut short and the damage to rolls decreased, remarkably improving the per tonnage rolled steel rate of roll consumption and needing very much less number of attending crew. All those, and the shortened time of rolling a coil, have improved the productivity greatly, as much as 1.5 times. Some factual results are shown in Fig. 19.

For another, thanks to the computing control, the amount of off-gage, though inevitable at the junctions of a coil to the next, is remarkably decreased to one fifth of conventional mill's as shown in Fig. 20. Also, because the tension can now be imposed on the strip all along its length, and thanks to the continually jetted coolant, not only the thermal deformation of the rolls has been practically eliminated and the strip shape stabilized, but the fluctuation of the temperature of rolling oil and of oil tank level is all but erased as may be seen in Fig. 21.

The less salient but equally important feature of 


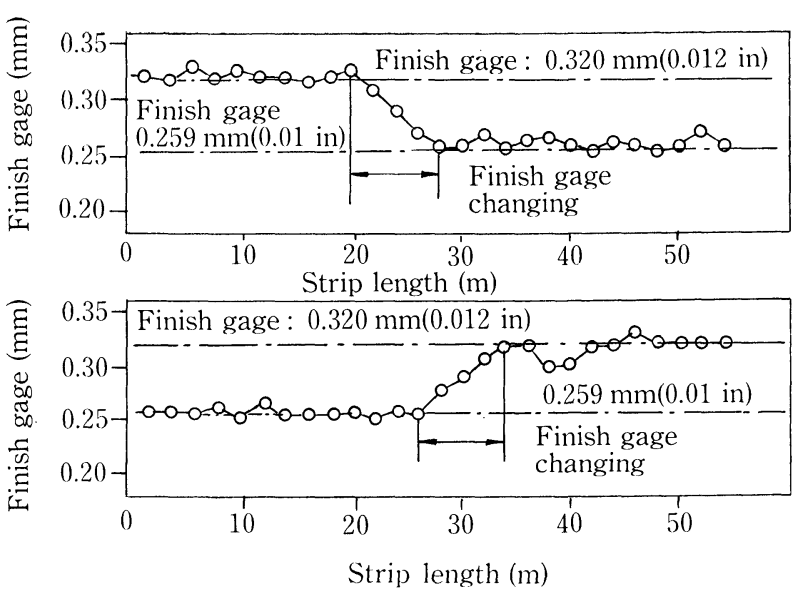

Fig. 20. Actual examples for chart record of flying gage change.

going to full continuous is the improvement in the work environment. That is to say, almost all the crew are now stationed in the central control room simply because there is very little they have to attend to on the floor.

\section{The 6-high Mill $^{36-40)}$}

Owing to the advancements achieved in AGC, the precision of strip thickness was improved greatly. The control of the shape, however, still remained dependent on the operator's skill because detection and controlling of it for the flying strip was not yet possible; it is only recently that a number of shape detectors and controlling methods have emerged.

To improve on this, several rolling mills have been developed. The more famous ones are the MKW (Mehrwalyem-Kalt-Walzwerke) mill, the 6-high mill, and the double chock bending mill. Of those, in the light of the two most important functions of shape control, namely, the shape stabilizing function, and the shape correction function, the 6-high mill is drawing a great attention.

\section{Outline of the 6-high Mill}

In a common 4-high mill, that portion of the work roll which extends out of the breadth of the work piece is subjected to additional bending moment, which gives rise to a large flexture in the work roll. Further, the bending effect of the work roll does not reach sufficiently well to the central part of the roll because it is under restraint of the backup roll to very near the ends. The 6-high mill, known as the $\mathrm{HC}$, or the high crown control, mill, has been devised to solve this problem.

The idea of the $\mathrm{HC}$ mill was first verified with a small research mill, then in 1974 to 1976 it was tried out on a reversing mill. In 1977 to 1978, further, one of the fore or the rear stands of a high speed 6 -stand mill was fitted with this 6 -high rolls designed specifically in accordance with the requirements of rolling. It was duly confirmed that the 6-high mill had features the ordinary 4-high mills did not possess.

\section{Principles and Structure of the 6-high Mill}

As illustrated in Fig. 22, in this 6-high mill a pair
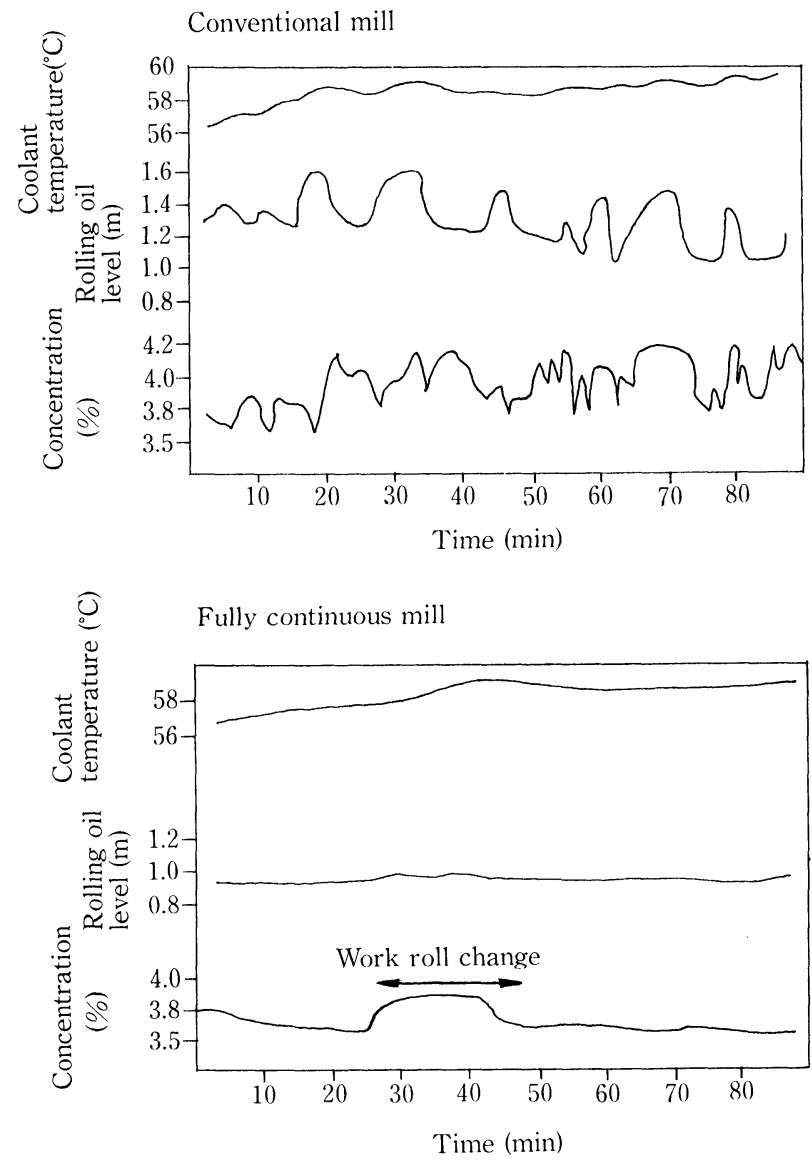

Fig. 21. Actual records of states of coolant.

of intermediate rolls are provided between the work and the backup rolls. These intermediate rolls can be shifted sideways, namely in their axial direction, so as to position their ends in accordance with the width of the work piece. Thanks to this, the work roll is disengaged at outside the work from the contact with the backup roll, so that it is no longer subjected to the effects of the backup roll's bending moment at its ends. This makes the flexture of the work roll markedly smaller to improve the shape of the work piece, and, at the same time, makes the effect of bending of the work roll much augmented to be able to obtain flatness for a wide range of strip width with zero initial crown for the work roll.

Those effects of the intermediate rolls are apparent in the 6-high mill's ability of taking greater reduction, the smaller diameter work roll, no need of providing the initial crown, marked decrease of edge drop, and others. As its superiority over conventional 4-high mills is very clear, it is being used in the skin pass mills as well as in the cold strip tandem mills, and introduction to hot strip mill is being contemplated.

\section{Continuous Annealing Line $\mathbf{4 2}^{\mathbf{4}}$}

The making of cold rolled sheet steels of deep drawing grade for automotive or electric home appliances use has long been a time-consuming work: it has to go through electrolysis cleaning, batch annealing, cooling of coil, temper rolling, and inspec- 

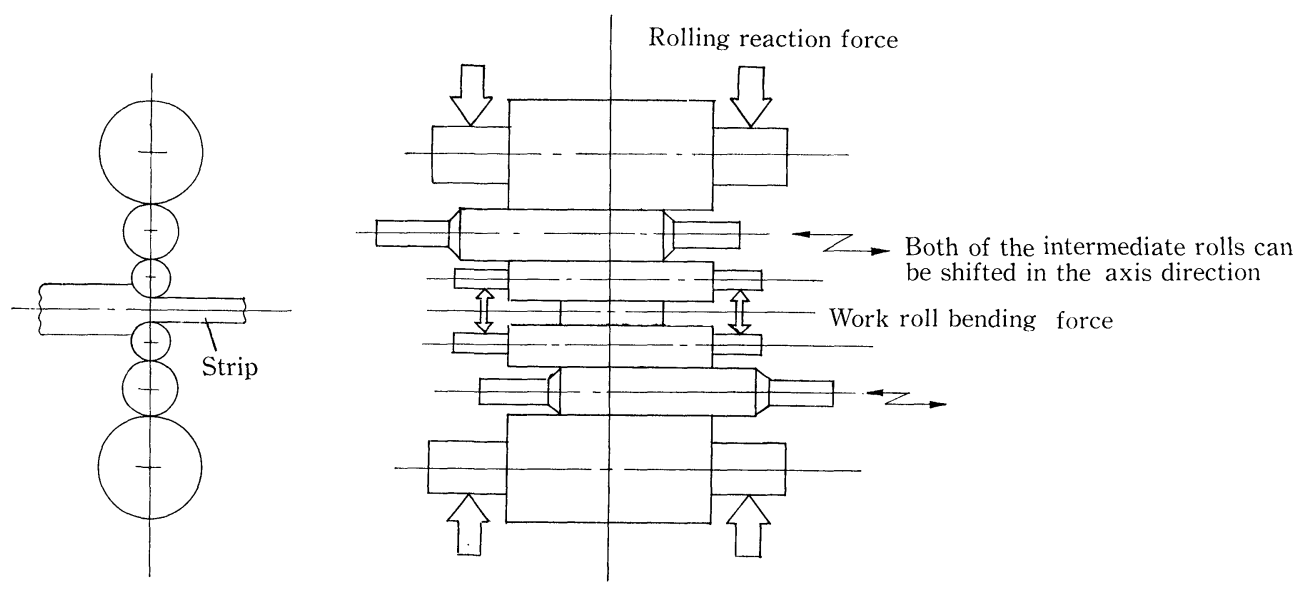

Fig. 22.

Structure of 6-high mill.

tion and grooming. Of those, the batch annealing had for some time been replaced with continuous annealer when making tinned or galvanized sheets, which require no particularly good formability.

For deep drawing steel, however, the material has to go through quick heating, then, in close succession, hardening by quenching. It was the difficulty of meeting those two metallurgical requirements as well as another one of equipment technology, that of concatenating those five independent processes into one and single apparatus, that had been holding the progress up for a long time.

This very difficult proposition was finally realized in a form of fully continuous annealing line, and several of them were developed and installed successively in 1971 and 1972.

\section{Outline of Continuous Annealing Line}

The representative of the continuous annealing lines are the CAPL and the NKK-CAL, which are respectively shown in Fig. $23^{41)}$ and Table 5. ${ }^{42}$ In short, they are composed of, from the entry end towards the delivery, the electrolysis cleaning unit, the furnace unit, the temper rolling mill unit, and the inspection and grooming unit.

\section{(1) The Front End}

In the front part, the cold rolled coils are welded together one by one and fed, with the lubricant oil removed, into the furnace part as one continuous strip at a constant speed. It is composed, as shown in Fig. 23, of a pair of pay-off reels, a welder, an electrolysis unit, and an intake looper. To execute the coil change in a minimum possible time, the pair of pay-off reels is activated alternatively, and the narrow lap seam welder ensures a good joint that takes many bendings to be given by the hearth rollers through the line. The time needed to switch the reel is about $40 \mathrm{sec}$.

The electrolysis cleaning unit is composed of the chemical cleaning in an alkaline bath, the mechanical cleaning with brush rolls, and an electrochemical cleaning bath. The cleanser is ortho sodium silicate, and the electrolysis power source is of about $120 \mathrm{kVA}$ capacity.

(2) The Furnace Unit

In the furnace unit, the strip goes through five zones of the primary heating, the homogenization,
Table 5. Major specifications for CAPL and NKKCAL.

\begin{tabular}{l|l|l}
\hline & \multicolumn{1}{|c|}{ GAPL } & NKK-GAL \\
\hline Objects & $\begin{array}{l}\text { Cold rolled low carbon } \\
\text { strip steels* }\end{array}$ & Ditto. \\
Thickness $(\mathrm{mm})$ & $0.4 \sim 1.2$ & Ditto. \\
Strip width $(\mathrm{mm})$ & $750 \sim 1240$ & $610 \sim 1300$ \\
Coil weight $(\mathrm{t})$ & $45 \max$ & 32 max. \\
Line speed $(\mathrm{m} / \mathrm{min})$ & 200 & $180^{* *}$ \\
Furnace capacity $(\mathrm{t} / \mathrm{h})$ & 60 & 60 \\
\hline
\end{tabular}

* Includes JIS SPCC (the general purpose grade), SPCD (the drawing grade), and SPCE (the deep drawing grade).

** The speed through the furnace, at entry $225 \mathrm{~m} / \mathrm{min}$ and at exit $250 \mathrm{~m} / \mathrm{min}$.

maintained by electric resistance heating, the primary cooling, the overaging, the reheating, which is done either by electric resistance or by radiant tube, and the secondary cooling. The typical heating cycles of CAPL and NKK-CAL are shown in Fig. 24. ${ }^{41,42)}$ In the overaging treatment, which is one important process in the entire continuous annealing, the strip is quenched to below $500{ }^{\circ} \mathrm{C}$ so as to supersaturate the dissolved carbon, then reheated and kept to 300 to $450{ }^{\circ} \mathrm{C}$ to have the once dissolved carbide finely reprecipitated. The major difference between the GAPL and the NKK-CAL lies in the method of quenching in this primary cooling, in that the CAPL uses gas jet, whereas NKK-CAL relies on water quenching. The furnace atmosphere is a mixture gas of hydrogen and nitrogen for either, and the hydrogen content is usually 2 to $7 \%$.

The heating zone is designed to heat the strip up to $900^{\circ} \mathrm{C}$, and the heater is radiant tubes burning coke oven gas with a thermal input of 12000 to $16000 \times 10^{3} \mathrm{kcal} / \mathrm{h}$.

In the homogenization zone of CAPL, a $3000 \mathrm{~kW}$ electric heater is provided to keep the strip warm and to facilitate the heating of furnace after stopping of the line.

The strip temperature control, which had to be done on the basis of furnace temperature because of difficulty of measuring the strip temperature directly, should really be done by the temperature of strip 
(a)

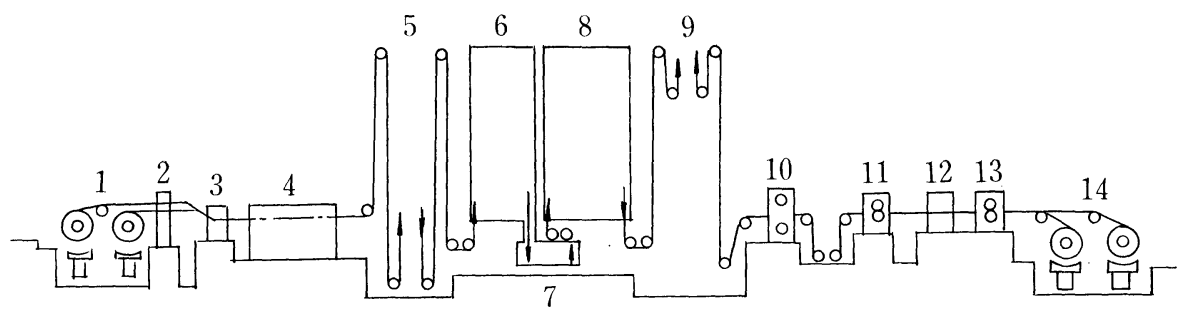

Entry apparatuses $\quad$ Furnace body Delivery apparatuses

(b)

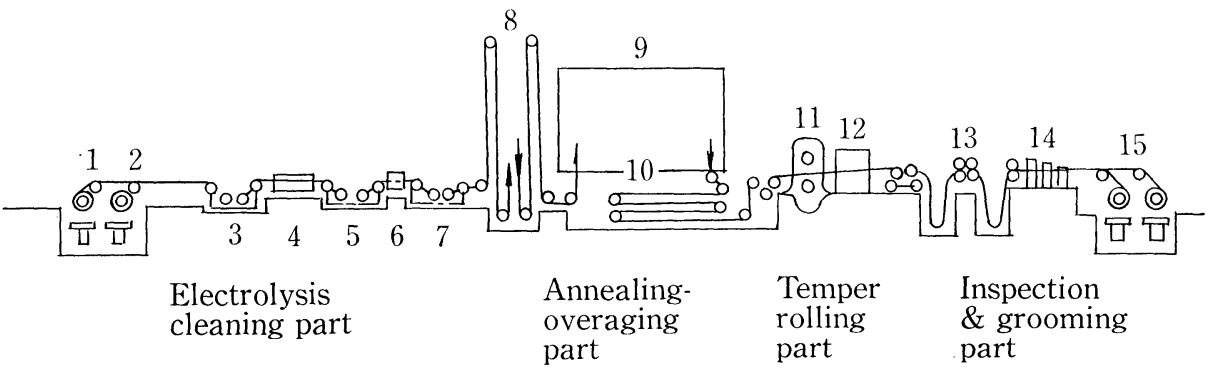
1. Pay-off reels (Nos. $1 \& 2$ )
2. Doublecut shear
3. Automatic welder
4. Electrolysis cleaning unit
5. Entry looping tower

6. Recrystallization annealer 11. Side trimmer

7. Quench chamber 12. Oiler

8. Overaging chamber 13. Drum shear

9. Delivery looping tower 14. Tension reels (Nos. 1 \& 2)

10. Temper rolling mill

(a) NKK-CAL

1. No. 1 payoff reel

2. No. 2 payoff reel

3. Hot caustic tank

4. No. 1 plan scrubber

5. Electrolysis tank

6. No. 2 plan scrubber

7. Rinse tank

8. Entry looping tower

9. Continuous furnace

10. Exit looping car
11. Temper rolling mill
12. Tension leveler
13. Side trimmer
14. Oiler
15. Tension reels (Nos. $1 \& 2$ )

Fig. 23. The two representative fully continuous annealing lines.

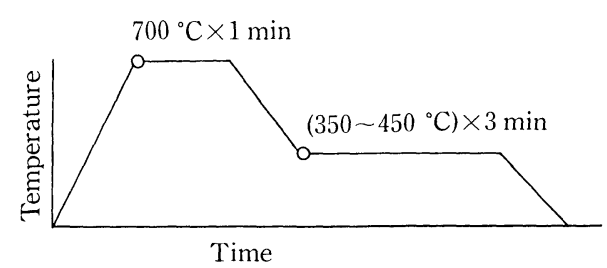

(a) CAPL

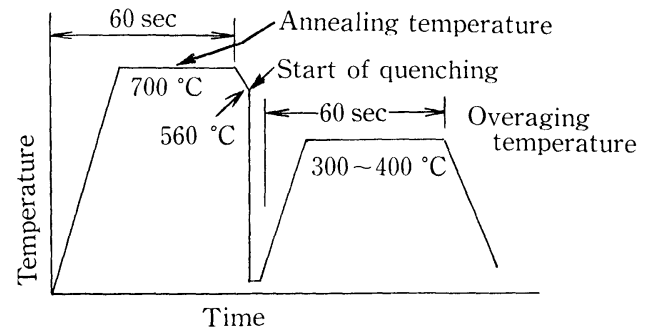

(b) NKK-CAL

Fig. 24. Examples of heat cycle for GAPL and UKK-CAL.

itself to ensure the quality. For this, an automatic direct strip temperature measuring control system has been invented for the GAPL, while a reference plate comparison method has been developed for the NKK-GAL. Those methods are illustrated in Figs. 25 and 26 , respectively.

In the primary cooling zone, in which cooling of strip to the overaging temperature is conducted, a rate of 5 to $30^{\circ} \mathrm{C} / \mathrm{sec}$ is achieved in CAPL by gas jet blown through water jacketed nozzles. In the NKK-CAL, on the other hand, very fast cooling rate of over $2000^{\circ} \mathrm{C} / \mathrm{sec}$ is assured on water quenching, shortening the time of overaging treatment appreciably. Here, the perfection of spray technique that does not deform the strip has been the key point.
For overaging, the strip temperature may simply be kept at a prescribed temperature in the CAPL, for which purpose a $4500 \mathrm{~kW}$ electric heater is provided. In the NKK-CAL, on the other hand, the strip has to be reheated following the water quenching, and for this purpose radiant tubes are provided for a thermal input of up to $9000 \times 10^{3} \mathrm{kcal} / \mathrm{h}$.

The secondary cooling is done by the gas jet, the atmosphere being cooled by water cooling or with a refrigerator so as to have the strip cooled to $40{ }^{\circ} \mathrm{C}$ and be fed to the temper rolling with no further ado.

The overall length of the strip within the continuous line can be as long as 800 to $1000 \mathrm{~m}$, and to prevent it from snaking, a number of steering rolls for centering are strategically provided. Also, as the strip is 


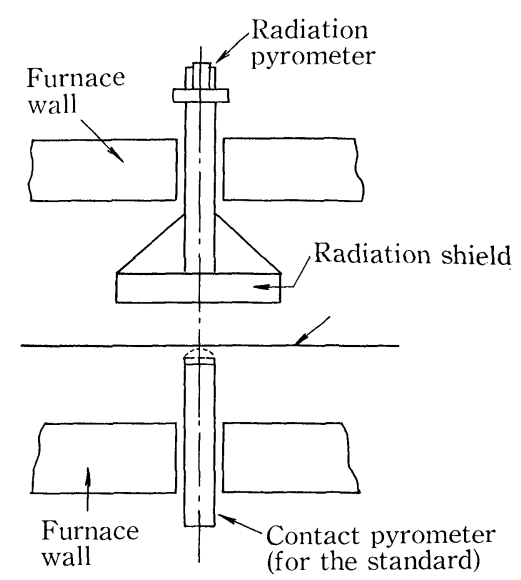

Fig. 25. The direct method of flying strip temperature measurement.
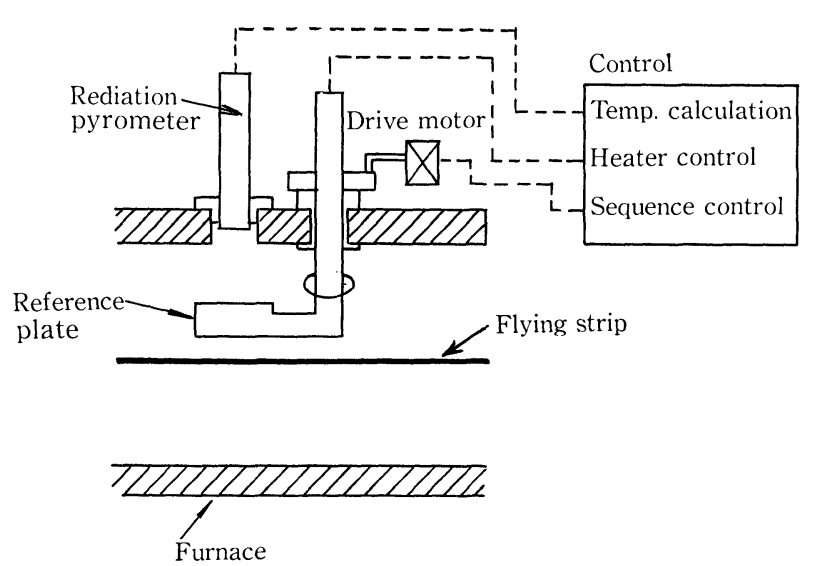

Fig. 26. The reference plate method of flying strip temperature measurement.

delicately stretching or contracting all differently under different heating and cooling states through those zones, the tension control is done independently for each zone.

(3) The Rear End

In the rear part, the dead soft annealed strip is given a light temper rolling to regulate its mechanical properties, groomed by trimming the sides, inspected, sprayed with oil, then coiled to a specified weight. For this, a takeout looper, a temper rolling mill, a pair of side trimmers, an oiler, a shear, and a pair of downcoilers are provided. To minimize the downtime at the outlet, the trimmer and the tension reel are provided by the pair besides a quick roll changer. Also, coils can be divided by the flying drum shear without making the suceeding strip to pause.

\section{Appreciation of Continuous Annealing Line}

The continuous annealing line technology is characterized not only by successful concatenation of five independent processes from electrolysis cleaning to grooming, but by the thorough rationalization of labor and redundant or overlapped works. A comparison with conventional method is shown in Table $6,{ }^{43)}$ where a great labor saving, energy saving, and cutting down of costs may be appreciated.

Besides those merits, because the continuous an-
Table 6. Merits of fully continuous annealing over conventional batch annealing (with CAPL as example).

\begin{tabular}{|c|c|}
\hline & Comparison* \\
\hline $\begin{array}{c}\text { Manufacturing } \\
\text { time }^{* 2}\end{array}$ & 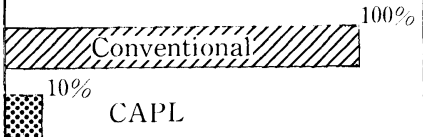 \\
\hline Attendants & 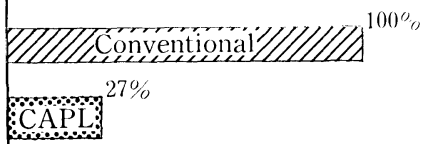 \\
\hline Area occupied & 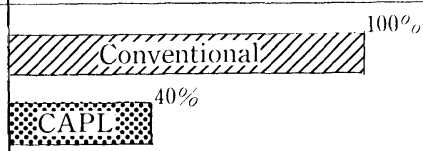 \\
\hline Capital cost*:3 & 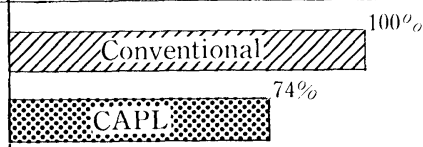 \\
\hline Yield loss & 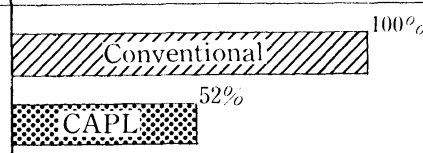 \\
\hline Energy & 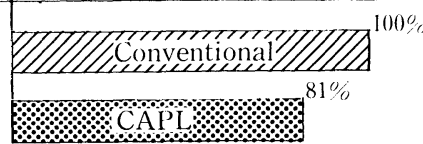 \\
\hline
\end{tabular}

*1 With the conventional batch process as 100 .

*2 For 10 days with the conventional process, CAPL is 1 day (actually $10 \mathrm{~min}$ ).

*3 Excluding the cost for the lot.

nealing line permits of a large flexibility in the heating rate, the heating temperature, and the cooling rate of the strip being treated, extensive application to making of high strength sheet steels and other new products is being held in good prospect.

\section{Recent Reeling Equipment-Continuous Reel-in and Reel-out Machine for Strip-making}

To keep pace with the automation in rolling and grooming processes, automation and continuation of pay-off and down-coilling of coils is indispensable. A number of apparatuses have been invented for this purpose, and the carrousel type reel is one of them.

\section{Features of the Carrousel Reel}

As may be seen in Fig. 27, the carrousel reel features the two bobbins provided on a revolving disk, one of which is at the service position either as a downcoiler or as a pay-off reel, while the other is at the waiting position, or $180 \mathrm{deg}$ off phase, taking out the wound coil or being prepared for receiving or paying off the next strip coil.

The greatest merit of using this machine is found in the greatly reduced work time, which is now less than one half of the conventional case as seen in the time schedules compared in Fig. 28. The second 
feature is the ease of coil handling, in that, as illustrated in Fig. 29, the paying off can be started directly from the top end handling position, which is higher than ordinary to afford good observation by the operator for both taking-in and taking-out of a wound coil. The third advantage is the smallness of the area needed, which is about one half of what the conventional twin reel equipment would occupy, though in the total cost they may not be too much different.

\section{Solving of Technical Difficulties}

As the carrousel reel itself is large and holds large components that rotate at a high speed, various problems like the resonant vibration of the drum had to be, and were duly, solved. For example, as the revolution of carrousel disk affects on the tension imposed on the strip under coiling-down or paying-off, a special revolution control that keeps the tension constant and minimizes the shock to the strip on stopping of the disk has been added. Also, to feed the work oil $\left(70 \mathrm{~kg} / \mathrm{cm}^{2}\right)$ into the carrousel disk and the lubricant oil $\left(5 \mathrm{~kg} / \mathrm{cm}^{2}\right)$ to gears and bearings, all from the ground to the rotating body, a large universal joint was newly developed.

\section{Continuous Rolling of $H$ Steels}

The $\mathrm{H}$ steel, which was first manufactured in this country in 1961 by the caliber rolling method, ${ }^{44)}$ has been on increasing demand for uses in structures that

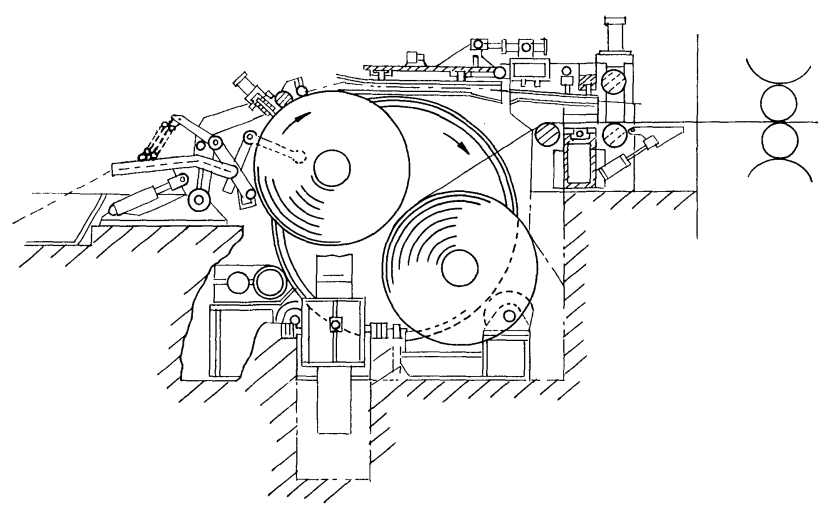

Fig. 27. The carrousel reel-in/real-out machine. were becoming larger and higher-rising for their large sectional moment and ease of handling.

The rolling of $\mathrm{H}$ steels, however, proved to be more complex than the plates. Yet, as theoretical analysis conducted on a research mill made fast progress, so did the computer control technique advance. The results have been the emergence of the semi-continuous mill, ${ }^{45,46)}$ then of the fully continuous mill, ${ }^{47)}$ replacing the conventional reversing mill. Figure 30 gives a comparison of those three mill layouts.

\section{Features of Fully Continuous Shape Rolling}

It is true that even today the $\mathrm{H}$ steels are being rolled by the universal mill aided by reversing edger, but in comparison with this practice, the continuous mill can boast markedly improved productivity on larger per pass reduction, greater products dimensional precision due to unvarying rolling conditions, and the manufacture of thinner gages due to higher finishing temperature. To develop those features fully, however, the interstand flying speed of the work stock must be controlled precisely. And, as the loop rolling, which is quite feasible with wire rods and small sections, cannot be applied to large sections, occurrence of tension or compression in between the stands is inevitable. Since this force can be an immediate cause for missrolling and damages to the equipment as well as can cause a large fluctuation in the product dimensions, a control system that holds the tensile or compressive force arising out of unbalanced material flow between two stands to zero, or at least to a minimum, has been in urgent need.

\section{Controlling of Continuous Mill}

The $\mathrm{H}$ steel rolling by universal mill has been extensively studied by means of plasticine experiments and by analyzing the data of operating mills, ${ }^{48}$ ) and also the effects of small diameter vertical rolls on the dimensional precision of products were subjected to strenuous study. ${ }^{49)}$ It was indeed on those researches that fully automatic continuous mill was commercialized.

Now, the ultimate purpose of continuous rolling is, as may be seen in Fig. 31, to equalize the volu-

\begin{tabular}{|c|c|c|c|c|}
\hline & Actions & Conventional reel & Actions & Carrousel machine \\
\hline 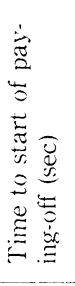 & $\begin{array}{l}\text { Drum closed } \\
\text { Coil car traversing } \\
\text { Drum opened } \\
\text { Coil car lift lowered } \\
\text { Threading } \\
\text { Pinch roll engaged } \\
\text { Threading }\end{array}$ & $\begin{array}{l}17(3400 \mathrm{~mm} 200 \mathrm{~mm} / \mathrm{sec}) \\
5(500 \text { at } 100) \\
5(1500 \text { at } 17.5 \mathrm{~m} \mathrm{~min}) \\
5(500 \text { at } 100) \\
17(1500 \text { at } 17 . \overline{\mathrm{m}} \mathrm{min})\end{array}$ & $\begin{array}{l}\text { Upper pinch roll } \\
\text { Lower pinch roll }\end{array}$ & $\bigsqcup_{10 \mathrm{sec}}^{5(500 \mathrm{~mm} \text { at } 100 \mathrm{~mm} \mathrm{sec})}$ \\
\hline 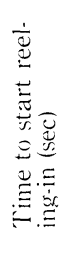 & $\begin{array}{l}\text { Strip passed through } \\
\text { Coil car lift raised } \\
\text { Drum closed } \\
\text { Coil car traversing } \\
\text { Drum opened } \\
\text { Belt wrapper adrancing }\end{array}$ & 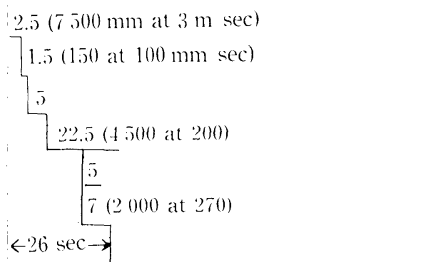 & & ame as $\mathrm{kft}$ \\
\hline
\end{tabular}

Fig. 28. Comparisons of temper mill reeling time schedule between conventional and carrousel. 

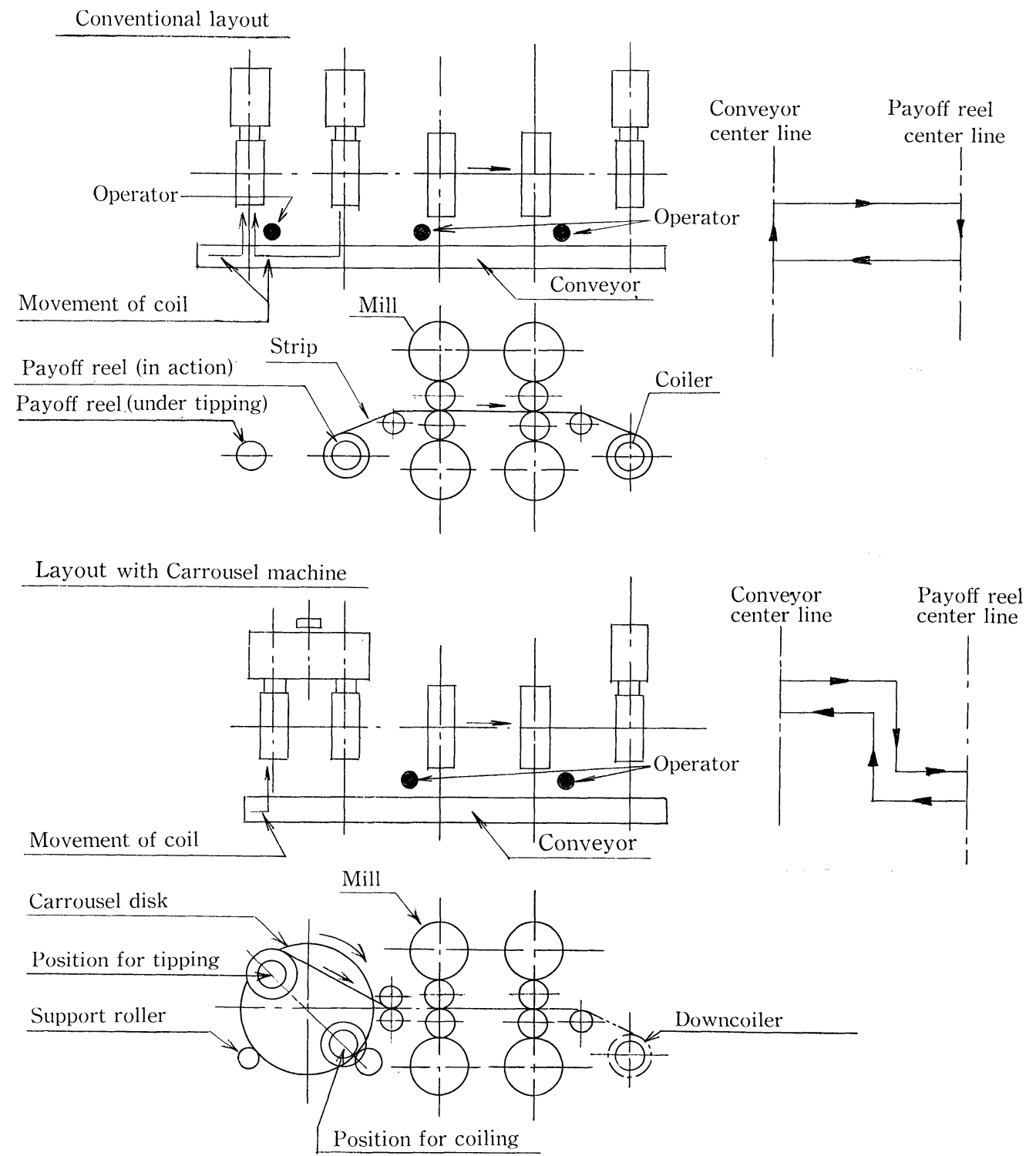

Fig. 29. Changes in temper mill work environment by the use of a carrousel machine.
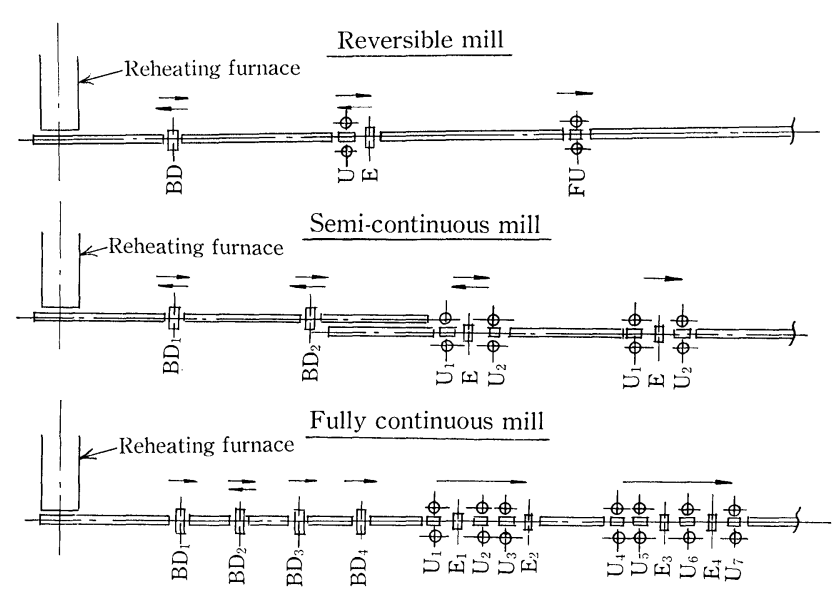

Fig. 30. The mill layout.

metric velocity of the steel at each stand so as to obtain products of invariable dimensions. For this, the deformation behavior under tension and the loading characteristics of the steel have been clarified by experimentation in a research model continuous mill, ${ }^{44)}$ in which the adaptability of lead as a simulator material was established. ${ }^{51)}$ This led to development of a mathematical model to enable calculation of the coefficients for tension between a given pair of stands, the transition between tensile and compressive states, the effects of such extrinsic perturbations as skid marks, thermal run-down, and ripples in the electric current, and the advancements or retardations. ${ }^{52)}$ Those studies gave foundation to the subsequent development of the AMTG (automatic minimum tension control), in which the motor current or the rolling torque is detected for controlling. ${ }^{52}$ Also, the interstand distance has become determined on consideration of the time of impact drop and that of occurrence of tension. Then, an advanced controlling, in which the rolling speed is corrected even for speed changes during impact drop or passing through, has been developed and actually used. ${ }^{44)}$ Figure 32 shows an effect of AMTG in terms of the changes in the flange width. ${ }^{44)}$

\section{An Example of Continuous Rolling Mill}

In Fig. 33, the layout of the world's first regular 
service fully continuous $\mathrm{H}$ rolling mill that was commissioned in 1972 is shown. ${ }^{47,53,54)}$ It is known for such features as:

(1) the great productivity, in that the mill is capable of manufacturing $80000 \mathrm{t} / \mathrm{month}$ against conventional mill's $50000 \mathrm{t}$, yet having a ready margin of expansion to $14000 \mathrm{t}$;

(2) the rougher train, which is composed of 4 roughers of $R_{0}, B D, R_{1}$, and $R_{2}$, the roughers being the once-through type and the breakdown mill the reversing type;

(3) the unique full automation on the AMTC, in which the intermediate train comprises three universal mills and the finishing train four universals and two edgers, all in tandem;

(4) the very fast roll change, in which the rolls and guides are cassetted for the quick three-position exchanger machine, ${ }^{55}$ ) while for the intermediate and finisher stands, double change type stand exchange

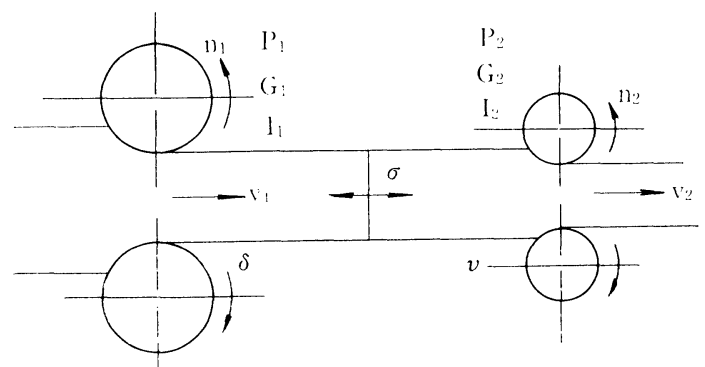

linst sland

Second stand

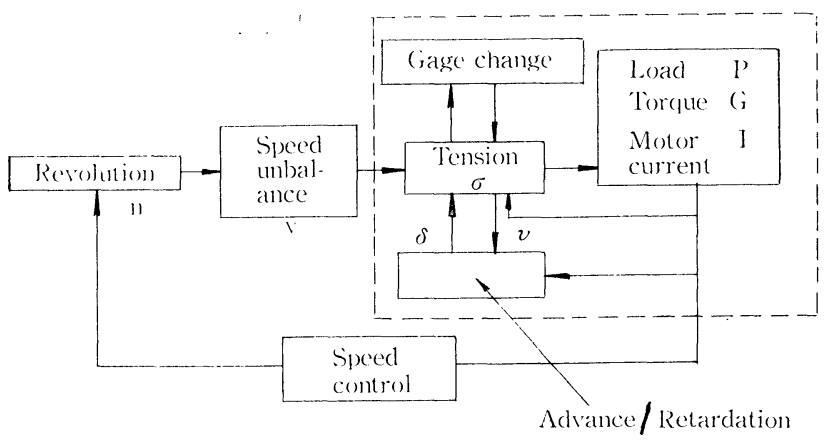

Fig. 31. Notion of continuous rolling. is practiced with the electric lines and the hydraulic pipes all instantaneously attached or detached by autocoupler; and

(5) the on-line controlled grooming line, in which the long $(130 \mathrm{~m})$ cooling bed, the long straightener, and the cold saw that can attend to several pieces in quick succession are controlled by a process computer, which also commands the sizing, stamping, classification, and bundling to carry the stock continuously into an automatic three-dimensional warehouse, which is, in its turn, fully automated from reception to shipping by a computer.

\section{High Speed Rolling of Wire Rods-The Block Mill56-58)}

What is so remarkable with modern wire rods mills is the adoption of the block mill in the finishing line, and this has been spreading fast since 1969. Owing to the block mill, the finishing speed, which remained at about $30 \mathrm{~m} / \mathrm{sec}$, was increased to 80 to $85 \mathrm{~m} / \mathrm{sec}$, and simultaneously with this, products of good dimensional precision and free from surface defects became to be had easily.

Of the block mills, the first was Cox's three rolls mill, followed by Morgan's No-Twist Mill, then Schlömann's and Demaag's, subsequently Mehler and Neumann's and Ashloe's joined force. Here, the features and advantages of block mill is presented with Morgan No-Twist Mill as an example.

The most fundamental difference to conventional finisher mills lies in the rolls and the roll drive mecha-

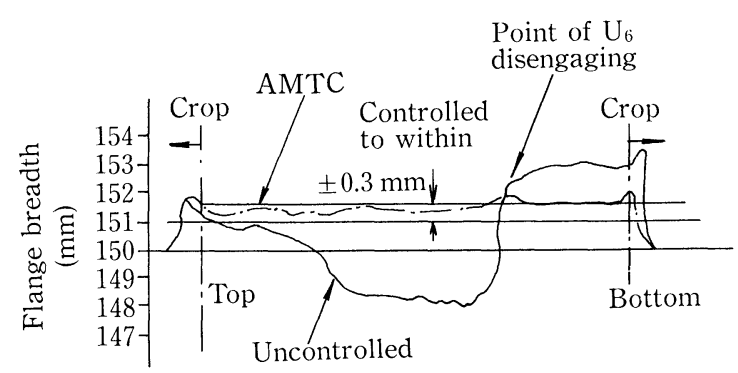

Fig. 32. Improvement in flange breadth precision due to AMTC (Automatic Minimum Tension Control).

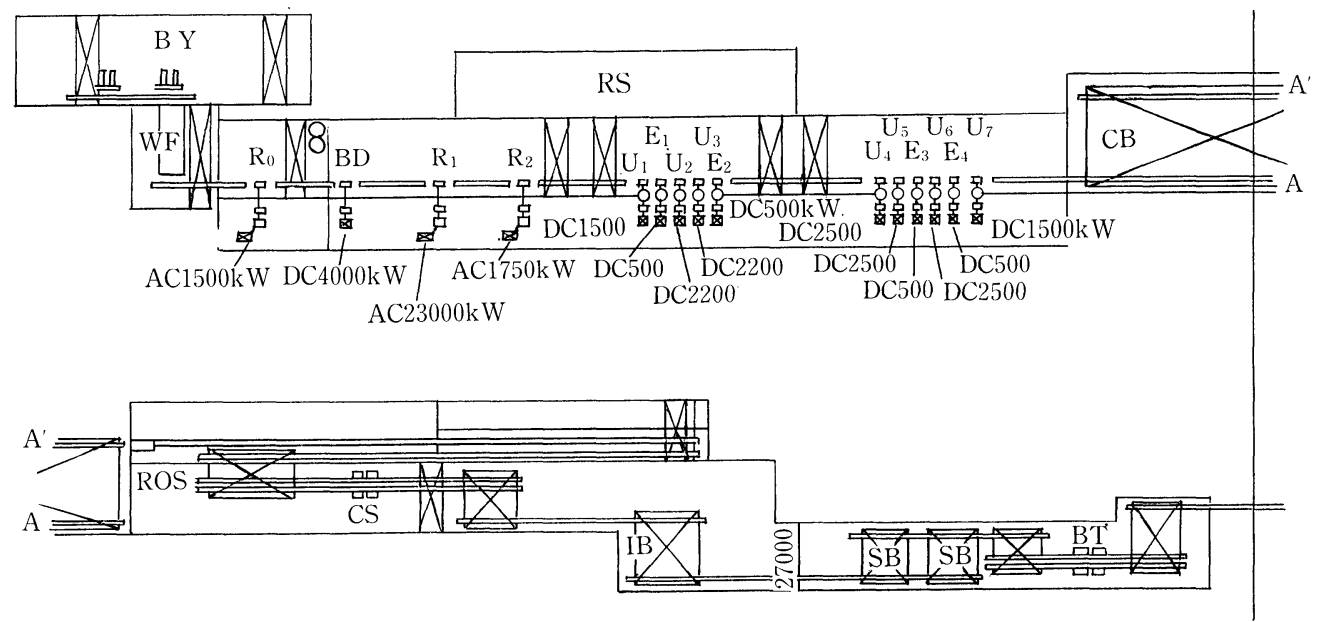

Fig. 33. An example of mill layout for large continuous rolling shop. 
nism, which are illustrated in Fig. 34 and compared in Table 7. Namely, the rolls are made of tungsten carbide for good durability, of the cantilever type to dispense with conventional mill spindles and couplings, which are the known sources of vibration, and are set in a frame in tandem, mutually inclined $45 \mathrm{deg}$ to the horizontal plane to cancel out the twisting. Though the caliber is only one to four to a roll, caliber change is easy because it is done by changing the rolls themselves by the frame. Also, as all the rolls are driven by a common drive with forward tension imposed, the awkward loop control is no longer necessary, making the line control considerably easier.

The second feature is found in the bearing, for which the three-layer slide bearing of $\mathrm{Cu}-\mathrm{Pb}$ alloy base metal is revived. An example is shown in Fig. 35.

The third is the lubrication, which is of a highly sophisticated one as may be seen in Table 8. This is to withstand the very severe lubrication conditions that come from the high speed, heavy load rolling. A special oil that is not only corrosion preventive but combines the characteristics of hydrodynamic lubricants and of gear oils has made its appearance recently.

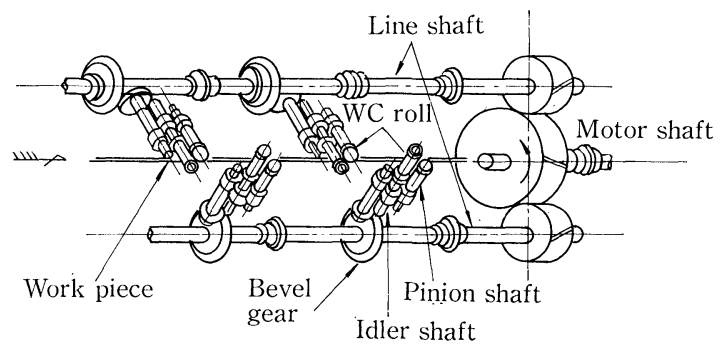

Fig. 34. Roll drive mechanism of the block mill.

\section{Direct Patenting}

Wires are rarely put to services as rolled, but generally they are submitted to a heat treatment known as patenting before use. This process is ordinarily conducted in an independent patenting furnace, but a method that utilizes the steel's sensible heat to achieve an effect almost equivalent to that by controlling the cooling rate right on the rolling line has been developed. This process is called the direct patenting.

As this method is well suited for handling large coils ( 1500 to $2000 \mathrm{~kg}$ ) to keep up with the high rate production of high speed mills, the method of controlled cooling, which is the central point in the direct patenting, has been a subject of intensive development. The first that emerged was the Stelmore Process, which was commercialized in 1964. In this method, the wire is quenched to about $800^{\circ} \mathrm{C}$, then laid out on a belt conveyor in a series of eccentric loops, and control-cooled by air jets blown from under to below about $400^{\circ} \mathrm{C}$. This is illustrated in Fig. 36 .

Subsequently, various other methods have been devised. The more famous ones are the vertically

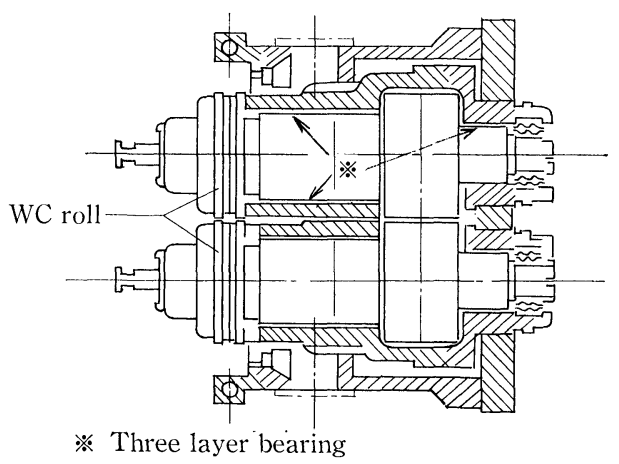

Fig. 35. Bearing for the block mill.

Table 7. Comparison between block mill and conventional mill.

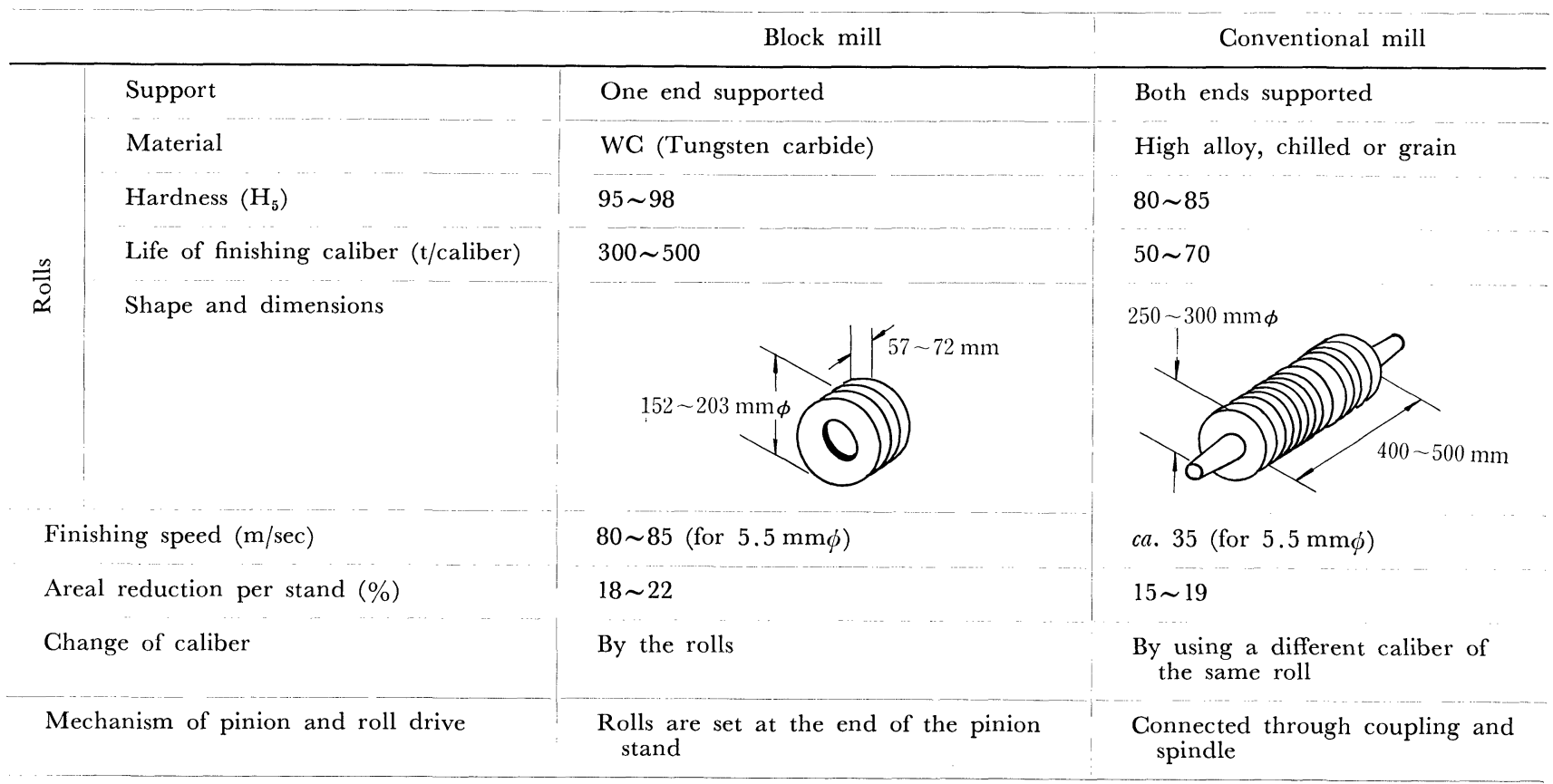


Table 8. Comparison of lubrication system between block mill and conventional mill.

\begin{tabular}{|c|c|c|c|c|c|}
\hline & & & & Block mill & Conventional mill \\
\hline \multicolumn{4}{|c|}{ Line filter specification* } & $10 \sim 25 \mu$ & $124 \mu$ \\
\hline \multicolumn{2}{|l|}{ Tank } & \multicolumn{2}{|l|}{$\begin{array}{l}\text { Number } \\
\text { Capacity*3 }\end{array}$} & $\begin{array}{l}2 * 2 \\
40 \sim 60 X\end{array}$ & $\begin{array}{l}1 \\
30 X\end{array}$ \\
\hline \multicolumn{2}{|c|}{ System components } & \multicolumn{2}{|c|}{$\begin{array}{l}\text { Centrifugal cleaner } \\
\text { Material for tank and valve }\end{array}$} & $\begin{array}{l}\text { Always in operation while the } \\
\text { mill is running } \\
\text { Stainless steel }\end{array}$ & $\begin{array}{l}\text { Put to work as deemed necessary } \\
\text { on inspecting the oil } \\
\text { Carbon steels and cast irons }\end{array}$ \\
\hline \multirow{3}{*}{$\begin{array}{l}\text { Controlling of } \\
\text { lubricant oil }\end{array}$} & \multicolumn{2}{|c|}{ Contamination } & $\begin{array}{l}\text { Control index*4 } \\
\text { Checking }\end{array}$ & $\begin{array}{l}\text { Weight method } 104 \sim 107 \text { by } \\
\text { NAS } \\
\text { Count method } 7 \sim 9 \text { by NAS } \\
\text { Once a month }\end{array}$ & $\begin{array}{l}\text { Change of oil if failed to meet } \\
\text { either index }\end{array}$ \\
\hline & \multicolumn{2}{|c|}{ Water content } & $\begin{array}{l}\text { Control index } \\
\text { Checking }\end{array}$ & $\begin{array}{l}0.1 \% \\
\text { Once a month }\end{array}$ & $\begin{array}{l}1 \sim 2 \% \\
\text { Once in } 3 \text { to } 6 \text { months }\end{array}$ \\
\hline & \multicolumn{3}{|c|}{ General checking } & Once a month & Once in 3 to 6 months \\
\hline
\end{tabular}

* Maximum size of the throughput

*2 Alternatively put to service

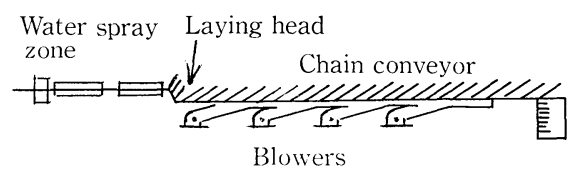

Fig. 36. The Stelmore direct patenting line.

descending conveyor method, the fluidized bed cooling method, and the boiling water cooling method. The working principles are shown in Figs. 37, 38, and 39 , respectively, and their features are summarized in Table 9.

It is well appreciated that the direct-patented stocks are of a refined pearlite structure, which is uniform all through the entire coil, and therefore of a good drawability and good mechanical properties that are comparable to, or often even better than, those of air patented wires. However, when compared to the lead bath patented wires, which are the best in quality, the direct-patented stocks are inferior in strength and in uniformity of quality. This is shown in Fig. 40 by comparing the drawability between the conventionally cooled wires and directpatented ones, and again in Fig. 41 by comparing tensile strength among the lead bath patented, directpatented, air patented, and conventionally cooled wires.

Though a considerable progress has been made, the direct patenting needs further development before it is accepted universally by all the mills.

(continues to Trans. ISIJ, 24 (1984), No. 4 (April))

\section{REFERENCES}

1) Katsura: Atsuen Gijutsu, Nikkan Kogyo Shimbunsha, Tokyo.

2) Kato: J. Japan Soc. Tech. Plasticity, 18 (1977), 583.

3) Sangyo Kikai, (1977), N, 13-47.

4) Fukuda: J. Japan Soc. Tech. Plasticity, 17 (1976), 550-559.

5) Satomi and Koike: Tetsu-to-Hagané, 59 (1973), 1846.

6) Sangyo Kikai Kogyo 30 Nen Shi.
*3 Multiples of the pump delivery $(l / \mathrm{min})$

*4 Renewal if failed for either one

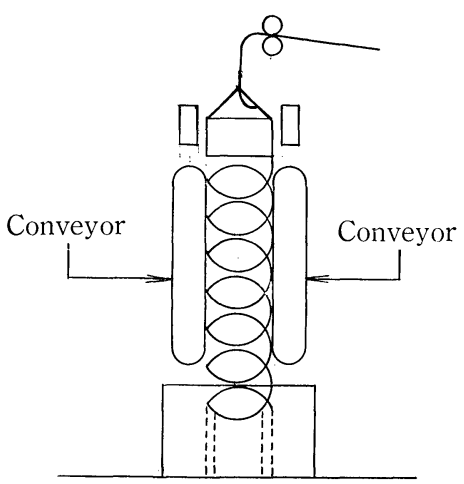

Fig. 37. The descending conveyor method of direct patenting.

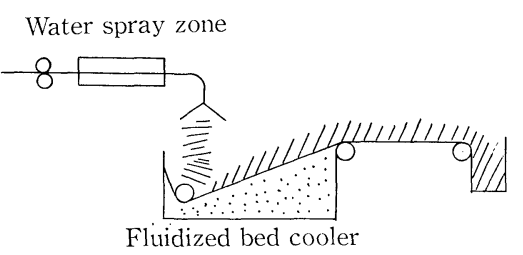

Fig. 38. The fluidized bed method of direct patenting.

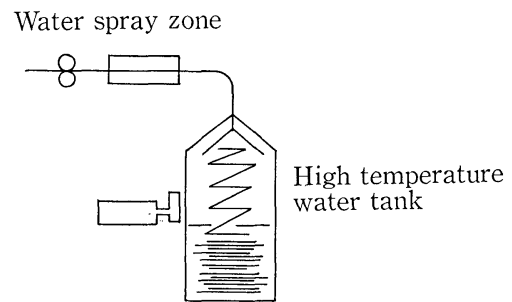

Fig. 39. The boiling water method of direct patenting.

7) Suzuki: J. Japan Soc. Mech. Eng., 78 (1975), 683.

8) Suzuki: Kikai no Kenkyu, 30 (1978), Jan.

9) Tetsu-to-Hagané, The 60th Anniversary Issue on Progress in the Science and Technology of Iron and Steel in Japan, 61 (1975), No. 5 
Table 9. Comparisons of various direct patenting methods.

\begin{tabular}{|c|c|c|c|}
\hline & Features & $\begin{array}{l}\text { Main } \\
\text { coolant }\end{array}$ & Quality of product \\
\hline Stelmore & $\begin{array}{l}\text { The wire, shaken out at the laying head } \\
\text { eccentrically, is moved by conveyor and } \\
\text { cooled uniformly by air blast. }\end{array}$ & Air blast & $\begin{array}{l}\text { - Mechanical properties equivalent to or even } \\
\text { better than the air patented stocks. } \\
\text { - Good drawability. } \\
\text { - Little scale loss. }\end{array}$ \\
\hline $\begin{array}{l}\text { Vertically } \\
\text { descending } \\
\text { conveyor }\end{array}$ & $\begin{array}{l}\text { The wire, shaken out into spiral, is held } \\
\text { between a pair of vertically descending } \\
\text { conveyors with a given pitch and air- } \\
\text { cooled. }\end{array}$ & Air blast & $\begin{array}{l}\text { - Mechanical properties equivalent to the air } \\
\text { patented stocks. } \\
\text { - Good drawability. } \\
\text { - Little scale loss. }\end{array}$ \\
\hline $\begin{array}{l}\text { Fluidized } \\
\text { bed cooler }\end{array}$ & $\begin{array}{l}\text { The wire is spirally and continually drop- } \\
\text { ped into a fluidized bed and cooled } \\
\text { uniformly. }\end{array}$ & Sand & $\begin{array}{l}\text { - Mechanical properties equivalent to or even } \\
\text { better than the air patented stocks. } \\
\text { - Good drawability } \\
\text { - Very little scale loss. }\end{array}$ \\
\hline Boiling water & $\begin{array}{l}\text { The wire is led into a hot water bath as } \\
\text { it is unwound from the coiler. }\end{array}$ & Hot water & $\begin{array}{l}\text { - Suitable for large lot. } \\
\text { - Good drawability. } \\
\text { - Very little scale loss. }\end{array}$ \\
\hline
\end{tabular}

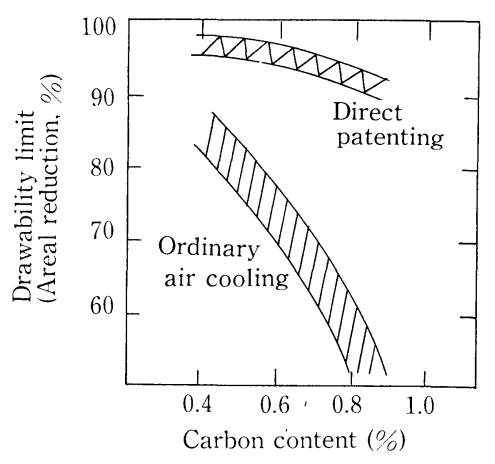

Fig. 40. Comparison of drawability.

10) Nosaka et al.: J. Japan Soc. Tech. Plasticity, 6 (1965), No. 59.

11) Hata et al.: The Hitachi Hyoron, 56 (1974), Oct.

12) Ichiyanagi et al.: The Hitachi Hyoron, 56 (1974), Oct.

13) Fukui et al.: The Hitachi Hyoron, 56 (1974), Oct.

14) Nomura et al.: Text of the 20th Memorial Symp. Rolling Theory Comm., ISIJ, June, (1974), 105.

15) Takeuchi et al.: J. Japan Soc. Tech. Plasticity, 14 (1973), No. 149.

16) Tsukii et al.: Ishikawajima-Harima Engineering Review, 16 (1976), No. 1.

17) Ishikawajima-Harima Engineering Review, 16 (1976), No. 4.

18) Mitsubishi Juko Giho, 9 (1972), No. 3.

19) J. Japan Soc. Tech. Plasticity, 16 (1975), No. 168.

20) Recent Development of Equipment and Operational Technology of Hot Strip Mills in Japan, ed. by ISIJ, Tokyo (1976).

21) Kakagowa Works, Kobe Steel Ltd.: Report to the 19th Cold Strip Subcomm., Steel Plate and Sheets Comm., Joint Research Soc., ISIJ, (1974).

22) Kashima Steel Works, Sumitomo Metal Industries, Ltd.; Mizushima Works, Kawasaki Steel Corp.; Nagoya Works, Nippon Steel Corp.: Report to the 27th Cold Strip Subcomm., Steel Plate and Sheets Comm., Joint Research Soc., ISIJ, (1974).

23) Chelyshen et al.: Steel in USSR, 12 (1977), 700-701.

24) Hüskm et al.: Stahl u. Eisen, 94 (1974), No. 5, 169-175.

25) Data due to Ishikawajima-Harima Heavy Industries Co., Ltd. and Nippon Steel Corp.

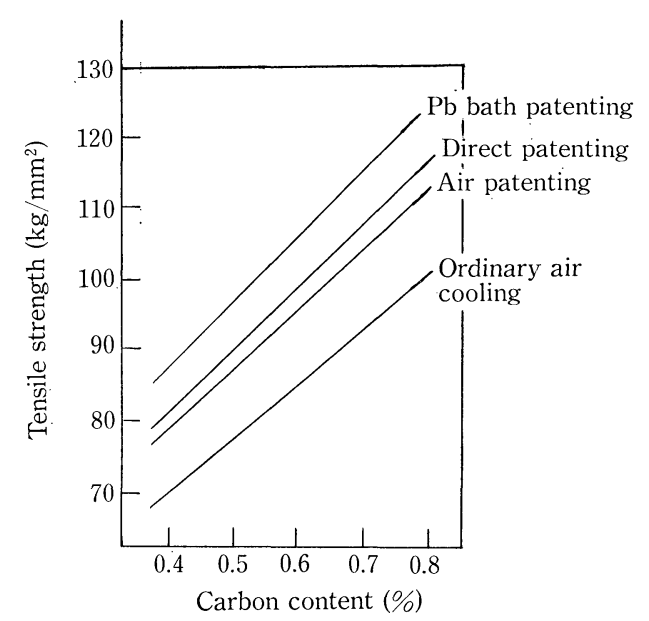

Fig. 41. Comparison of tensile strength.

26) Kohler et al.: Notes submitted to the Int'l Automation Conf., Düsseldorf, May, (1976).

27) Data due to Ishikawajima-Harima Heavy Industries, Co., Ltd. and Nippon Kokan K.K.

28) Data due to Mitsubishi Electric Corp. and Nippon Steel Corp.

29) Recent Development of Equipment and Operational Technology of Cold Strip Mill in Japan, ed. by ISIJ, Tokyo, (1977), 34.

30) Hodsolen et al.: Iron Steel Engineer, (1974), March, 49-53.

31) Gilmore: Iron Steel Engineer, (1976), Sept., 87-91.

32) Lenze: Stahl u. Eisen, 87 (1967). No. 14, 833.

33) Ichimaru and Hibino: Nippon Kokan Technical Report, (1972), No. 56, 57.

34) Arimura and Kamata: Text of the 20th Memorial Symp. of Rolling Theory Comm., The Joint Research Soc., ISIJ, June, 1974, (1974), 73.

35) Hibino and Ichimaru: Iron Steel Engineer, (1977), Feb., 33.

36) "Characteristics of HC-MILL", The Hitachi Hyoron, 56 (1974), No. 10.

37) "Characteristics of Rolling of HC-MILL", The Hitachi Hyoron, 58 (1976), No. 9.

38) Preprints of Plastic Working Joint Lecture Meeting, (1974).

39) Preprints of Plastic Working Joint Lecture Meeting, (1975).

40) Shida et al.: Text of the 20th Memorial Symp. of Rolling 
Theory Comm., The Joint Research Soc., ISIJ, June 1974, (1974), 185.

41) The 29-30th Nishiyama Memorial Seminar, ISIJ, Tokyo and Osaka, (1976).

42) Toda et al.: Tetsu-to-Hagané, 61 (1975), 91-94.

43) Tekkokai, (1974), July, 55.

44) Harada et al.: J. Japan Soc. Tech. Plasticity, 16 (1975), No. 168.

45) Morikawa and Yoshihara: Kawasaki Steel Tech. Report, 4 (1972).

46) Oyama et al.: Nippon Kokan Technical Report, (1972), No. 59.

47) Ishikawajima-Harima Engineering Review, 13 (1973), No. 1.

48) Nakajima et al.: Seitetsu Kenkyu, (1972), No. 275.

49) Kishikawa et al.: Patent Specification, S46-19167, (1971).

50) Nakajima and Watanabe: J. Japan Soc. Tech. Plasticity, 16 (1975), No. 172.

51) Nakajima and Watanabe: J. Japan Soc. Tech. Plasticity, 13 (1972), No. 141.
52) Tsuji et al.: Mitsubishi Denki Giho, 1 (1974), No. 2.

53) Toko et al.: Seitetsu Kenkyu, (1973), No. 279.

54) Kimitsu Works, NSG: Report to the 20th Large Section Subcomm., ISIJ.

55) Kukan: Patent 1015472.

56) Sannomiya: Text of the 20th Memorial Symp. of Rolling Theory Comm., The Joint Research Soc., ISIJ, June, 1974, (1974), 253.

57) Tomioka: Tetsu-to-Hagané, 59 (1973), 1726.

58) '77 Seitetsu Kikai Setsubi Soran, Jukogyo Shimbunsha, Tokyo, (1978).

59) Takeo and Iwata: Bull. Japan Inst. Metals, (1975).

60) Harada: The 17th Nishiyama Memorial Seminar, (1972).

61) Sannomiya: Text of Rolling Theory Comm., The Joint Research Soc., ISIJ, (1974).

62) Nakamura: Kinzoku, (1977), Special Issue,

63) "New Controlled Cooling Process Improves Tensile Strengths ", Steel Times, (1977), Dec. 